\title{
Air Pollution, SARS-CoV-2 and the Wider Implications - An Overview of Recent Events with a Focus on Italy
}

Special Issue:

Special Issue on COVID-19 Aerosol Drivers, Impacts and Mitigation (XVI)

\section{Pierre Madl ${ }^{1 *}$, Clemens Arvay ${ }^{2}$, Antonietta Gatti $^{3}$, Livio Giuliani ${ }^{4}$, Herbert Lettner ${ }^{1}$}

\author{
${ }^{1}$ Department of Chemistry and Physics of Materials, University of Salzburg, Salzburg, Austria \\ ${ }^{2}$ Independent scientist and textbook author in Health Ecology, Vienna and Graz, Austria \\ ${ }^{3}$ Nanodiagnostics Laboratory, San Vito (Modena), Italy \\ ${ }^{4}$ ECERI (European Cancer and Environment Research Institute), Bruxelles, Belgium and ICEMS \\ (International Commission for Electromagnetic Safety), Venice, Italy
}

\section{OPEN ACCESS}

Received: August 28, 2020

Revised: June 9, 2021

Accepted: June 116, 2021

${ }^{*}$ Corresponding Author: pierre.madı@sbg.ac.at

\section{Publisher:}

Taiwan Association for Aerosol Research

ISSN: $1680-8584$ print

ISSN: 2071-1409 online

Copyright: The Author(s). This is an open access article distributed under the terms of the Creative Commons Attribution License (CC BY 4.0), which permits unrestricted use, distribution, and reproduction in any medium, provided the original author and source are cited.

\section{ABSTRACT}

Since the outbreak of coronavirus disease 2019 (COVID-19) associated with the novel SARS-CoV-2, infections have spread worldwide. In part-I of our article, we show that the specificity of the speed of increase in COVID-19 cases over northern Italy, one of the most affected regions, strongly correlated with prevailing conditions of ground-level air pollution notably during the colder months of the year. Particularly striking were excessive concentrations of $\mathrm{PM}_{10} / \mathrm{PM}_{2.5}, \mathrm{NO}_{2}$ and shortfalls within the Italian health-care system, which aggravated the health crisis that followed thereafter. In part-II, we highlight that SARS-CoV-2 is just a tiny contributor in an already overstressed environmental setting that tilted the balance towards a new steady state, which is reflected by an increased viral susceptibility among the residence of the wider Po-Valley then elsewhere. Both the currently opted counter strategies imposed by authorities as well as hasty efforts with regards to the development of vaccines point at a "crisis of perception" rather than a well-designed strategy that includes a wide range of possible options. Therefore, this contribution looks at the missed opportunities in tackling poor urban air quality, at the dynamics of bioaerosol spreading including the associated atmospheric factors, at the challenges ahead when interfering with viral competences in multicellular organisms, the risks associated with poorly tested genetic-based vaccines, the induced neuro-psychological effects as a result of the unilateral measures imposed by authorities, and the likelihood that COVID-like events are becoming a regular phenomenon.

Keywords: Chronic urban air pollution, SARS-CoV-2, COVID-19, Bioaerosol, Vaccination, Psychoneuro-immunology

\section{INTRODUCTION}

The epidemic progression during the first wave of the severe acute respiratory syndrome coronavirus 2 (SARS-CoV-2) and its associated disease COVID-19 in northern Italy had its most dramatic impact in certain hotspots across the Po-Valley, stretching from north-western provinces such as Piedmont, Lombardy all the way to towards the north-east affecting even Emilia Romagna and Veneto. Upon the emergence of the first cases on January $30^{\text {th }}$ (two Chinese tourists with COVID-19 symptoms hospitalized on same day) followed by a third one a few days later (an Italian citizen repatriated from WuHan, CHN), induced a sharp rise of cases. In a first response, state authorities appealed on inter-personal distance keeping, announced hygienic codes of conducts, enforced the use of obligatory face-masks and eventually introduced quarantine measures to minimize the spread. Yet, as the number of COVID-19 cases exploded by the end of February, with Lombardy peaking with 615 cases, Emilia Romagna 217 and Veneto 191 (WHO, 2020b), authorities 
issued travel restrictions, announced curfews, and closed schools, museums, theatres, as well as all public gatherings (sporting events. etc.) among the most hard-hit areas in the province of Lombardy. On the $9^{\text {th }}$ of March, COVID-19 cases have been registered across the state, and as the situation further precipitated prompted authorities to adopt the "Chinese countermeasure strategy" by proclaiming a nation-wide lockdown with only essential economic activates still operational (Pepe et al., 2020). These measures though, could not prevent an-all time high of COVID-19 positives, which followed two weeks later.

The medical emergency was also triggered due to the lower number of intensive care units (ICUs) available in Italy compared to northern Europe (Walach and Hockertz, 2020; WHO, 2020b) and an unfavorable demographic constellation with a higher share of elderly $>70 \mathrm{yrs}$ of age (Perone, 2021). The situation induced fear and panic among many, which was not only limited to most Italians, but affected also many across Europe. The psychological stress imposed on an individual level was further fuelled by the discussions about facemasks and their effectiveness often not based on scientific findings. This discussion did not fade out even when the WHO (2020a) proclaimed that SARS-CoV-2 might spread mostly via aqueous droplets, which can be shielded by ordinary surgical masks. Only by July $4^{\text {th }}$, long after the first wave swept over Italy, the New York Times published an open letter of 239 scientists "With One Big Claim: The Coronavirus is Airborne" (Mandavilli, 2020), which argued that the indoor use of the more sophisticated N95 mask is warranted. This recommendation, based on the standard NIOSH-42CFR84 (technically identical to EN 149-2001) defines the features of FFP2 masks, which demands that masks filter up to 95 percent of airborne particles, with diameters $>30 \mu \mathrm{m}$. In principle, neither N95 nor FFP2 masks can provide the required safety as infectious viral particles (virions), as picoRNA viruses such as SARS-CoV, MERS, H1N1, H2N5 or Influenza A, are in the size range of $0.1 \mu \mathrm{m}$ (Mclntosh, 1974; King et al., 2011). The experimented efficacy of a N95 mask (CDC, 2020a), can only be justified when virions are embedded within micron-sized dust/liquid particles to become "filterable". The only benefit that wearing a mask entails regard the drastic reduction of expired air velocities and as such limits viral spreading (Hsiao et al., 2020). However, individuals not fully aware on how to properly use facemasks, particularly with "cheaper" versions, potentially create microclimatic conditions that promote the growth of microorganisms and viral populations under constant humidifying conditions during prolonged usage (Maclntyre et al., 2015), or induce headaches due to the release of volatile organic compounds (VOCs) from premade single-use-facemasks (Lim et al., 2006). In sensitive individuals, such incubator-like conditions aggravate the situation (as both viruses and bacteria remain viable) rather than aiding in their protection against potential pathogens - particularly when suffering already from a respiratory infection or when affected by Chronic Obstructive Pulmonary Disease (COPD) or asthma.

Interestingly, instead of elaborating alternative strategies as the first wave subsided, Italy along with most other EU-member states adopted the same "sheltering" attitude for the second wave, which took off in fall of 2020. Accordingly, we first address issues regarding urban air pollution, by considering facts and figures available from various sources, only to focus then at the erratic counter-measures taken by both Italian authorities and other EU-member states (instead of conducting a publicly open discussion about softer strategies that some countries like Sweden or the US-state of Florida have opted for). In fact, we are criticising the methods used to contain the spread of the disease as in our eyes it obfuscates the underlying drivers and do not limit the associated health problems. SARS-CoV-2 did not pop up accidentally, but rather is the result of culminating systemic alterations induced by anthropogenic activities. So, the goal of this paper is to shed light on i) the current status quo, particularly on the prevailing air pollution inventory and its co-modulating effect on bioaerosols such as SARS-CoV-2, ii) the viral sphere, its dynamics and its relevance for biology, and iii) address the current counter-strategies adapted by most EU-member states that consider the development of vaccines as the only available opt-out perspective.

\section{PART-I PERSISTENT AIR POLLUTION ACROSS THE PO-VALLEY}

\subsection{Health Effects of Persistent Air-pollution during the Cold Season}

The strong regional differences in the propagation of COVID-19 infections point at several co-modulating factors, and with regard to northern Italy it is the poor air quality that tops the 
agenda (Zoran et al., 2020). Geographically, northern Italy is somewhat encapsulated by the alpine arc (NE to NW) and the Apennine mountain range (S), which limits the exchange of air masses and as such favouring the accumulation of combustion-related exhaust products during winter (Zoran et al., 2020). The dominating pollution-sources regard internal combustion engines, household heating systems as well as industrial activities contribute to the accumulation of respirable airborne particles in urban air. In addition, 20 of the 73 fossil-fuel operated large-scale power plants (>100 MW) are located within the Po-Valley, along with 27 of Italy's 56 waste incinerators; the huge facility in the Brescia-Bergamo area emits a plume of nanoparticles that is detectable even in blood-samples of individuals living nearby (Gatti and Montanari, 2015) using state of the art nano-technological diagnostic tools (Gatti and Montanari, 2008).

The pathways of entry into the human body are manifold but the lion-share enters via the respiratory tract. The coarse particle fraction (known as $\mathrm{PM}_{10}$, with aerodynamic diameters $\leq 10 \mu \mathrm{m}$ ) are predominantly deposited in the extra-thoracic region such as nose and throat, and usually contribute to soreness and dryness of the upper respiratory tract (Addey and Shephard, 2012; Vallero, 2014). The fine particles fraction (known as $\mathrm{PM}_{2.5}$, with aerodynamic diameters $\leq 2.5 \mu \mathrm{m}$ ) is inhalable and does reach down to smaller airways (mostly bronchi and bronchioles), where in high concentrations can irritate the lung lining to induce coughs (Hofmann, 2011). In sheer numbers though, the ultrafine particle (UFP) fraction ( $<100 \mathrm{~nm}$ in aerodynamic diameter) account for $>90$ percent of airborne pollutants, are readily inhaled and as such tend to deposit in the alveolar regime of the lungs, thus are able to easily trespass into the bloodstream (Hofmann, 2011). Once there, these nanoparticles exert organismic-wide effects and are responsible for numerous pathologies that are usually not associated to air pollution (Oberdoerster et al., 2005).

Moreover, in chronically polluted air nitric dioxide $\left(\mathrm{NO}_{2}\right)$ is a very peculiar co-ingredient, and in association with PM, is a notorious inducer of inflammation-related cascades and oxidative stress impairing cellular function (Lodovici and Bigagli, 2011). Oxidative stress affects the endotheliumderived mediator, nitric oxide (NO), resulting in the build-up of detrimental mediators such as peroxy-nitrite, limiting the body's NO-mediated vasodilating potential, thereby inhibiting platelet activation/aggregation, and suppressing smooth muscle cell proliferation (Miller et al., 2012). $\mathrm{NO}_{2}$ is also linked to bronchitis in asthmatic children and known to reduce lung functions at much lower levels than those shown in Fig. 2 (Vallero, 2014). The adverse effects are much heavier though, when exposed individuals suffer already from acute respiratory infections (Chauhan and Johnston, 2002).

In order to perceive the extent of the toxic load dispersed across the wider Po-Valley, the Tropomi instrument aboard the Copernicus Sentinel-5P satellite is an excellent remote sensing tool as it is capable of mapping a variety of air pollutants, including $\mathrm{NO}_{2}$-concentrations (Chimot, 2021). Fig. 1 visualizes the distribution of $\mathrm{NO}_{2}$-emissions across Europe, particularly the drastic accumulation over the entire Po-Valley as the first wave of COVID-19 incidents swept across Europe (ESA, 2020). As will be shown later, prolonged exposure to nitric oxides induces chronic irritation of the respiratory tract and therefore must be considered as a booster in COVID-19 frequencies. The data illustrate a rapid decline of $\mathrm{NO}_{2}$ concentrations particularly over the Po-Valley, the Beneluxcountries as well as major cities across Europe-such as Milan, Paris and Madrid that coincided with the imposed lockdowns.

$\mathrm{NO}_{x}$-production and Diesel exhaust particles (DEP) go hand in hand, with the latter being known as strong promoter to atherosclerotic plaque formation, which in turn is directly related to myocardial infarction (Miller et al., 2013). These combustion-related by-products are attributed to increased rates of mortalities among the exposed urban population (Dockery et al., 1993; Gan et al., 2011; Cesaroni et al., 2013; Cesaroni et al., 2014; Miller, 2020).

The distribution of ground-level air pollutants $\left(\mathrm{NO}_{2}, \mathrm{PM}_{2.5}\right.$ and $\left.\mathrm{PM}_{10}\right)$ in Italian regions over the last four years regularly exceed the consented safety limits of 35 days/year, assigning Northern Italy as "the" air pollution hot-spot not just in Italy but topping even the upper ranks at the EUlevel (Fattorini and Refoli, 2020; Srivastava, 2020; Zoran et al., 2020). The frequent infringements of the legal threshold values $\left(50 / 25 \mu \mathrm{g} \mathrm{m}^{-3}\right.$ for daily $\mathrm{PM}_{10} / \mathrm{PM}_{2.5}$ concentration) are visible in Fig. 2 . It shows how often the daily averages exceeded legal limits during the first wave, while Fig. 3 provides the same trends from a continental perspective (AirVisual, 2020, see Babu et al. (2020) and Zoran et al. (2020) for how a single AQI-value can be calculated using a multitude of pollutant source terms such as $\mathrm{O}_{3}, \mathrm{NO}_{2}, \mathrm{PM}_{10}, \mathrm{PM}_{2.5}, \mathrm{SO}_{2}$, and $\mathrm{CO}$ ). 

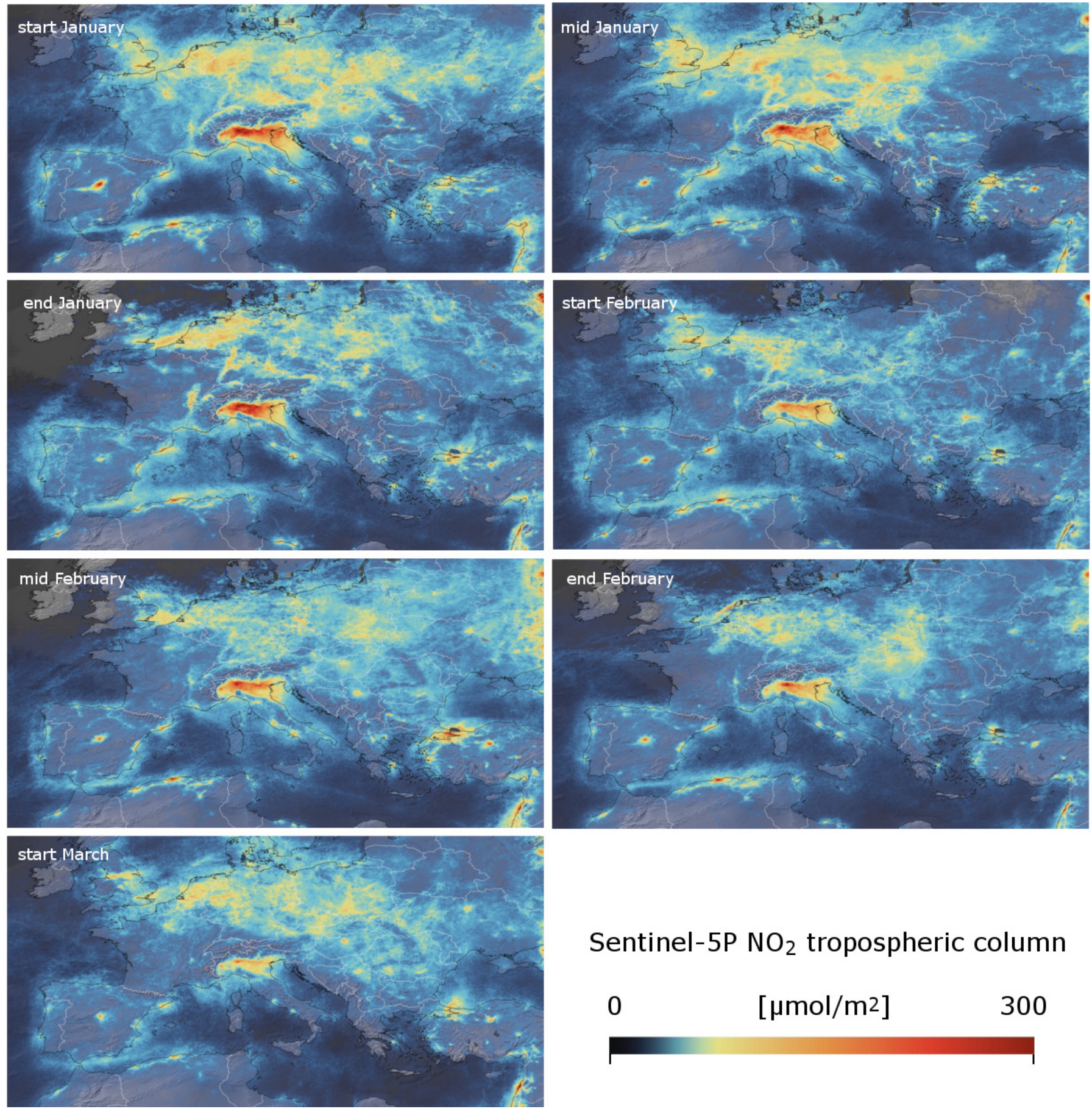

\section{Sentinel-5 $\mathrm{P} \mathrm{NO}_{2}$ tropospheric column}

0

$\left[\mu \mathrm{mol} / \mathrm{m}^{2}\right]$

300

Fig. 1. Snapshots of the $\mathrm{NO}_{2}$-emission drop over the Po Valley in late winter/spring 2020 as monitored by the ESA 10-day moving average animation covering a time frame from 1 January until 11 March 2020 (compilation based on ESA, 2020).

Indeed, $\mathrm{NO}_{2}$ and Ozone $\left(\mathrm{O}_{3}\right)$ are tightly related as $\mathrm{NO}_{2}$ is a precursor for both tropospheric $\mathrm{O}_{3}$ and particles. It forms nitrate aerosols which are a major constituent for $\mathrm{PM}_{2.5}$ and in presence of UV-exposure readily converts to $\mathrm{O}_{3}$ (Vallero, 2014). In terms of ozone, legally binding concentrations of ground level $\mathrm{O}_{3}$ for an $8 \mathrm{~h}$ mean is currently set to a threshold value of $120 \mu \mathrm{g} \cdot \mathrm{m}^{-3}$ (EU, 2008). As meteorological conditions have a great impact on $\mathrm{O}_{3}$ concentrations, it optimally forms on hot, sunny days under stagnant wind conditions. Fig. 2 also reveals that $\mathrm{O}_{3}$-threshold levels have been violated only once, three months after fatalities due to COVID-19 peaked. Nonetheless, $\mathrm{O}_{3}$ does affect people's health as it induces a variety of toxic effects in humans including morphologic, functional, immunologic, and biochemical alterations. An increment of $10 \mu \mathrm{g} \cdot \mathrm{m}^{-3}$ in $\mathrm{O}_{3}$-concentration 


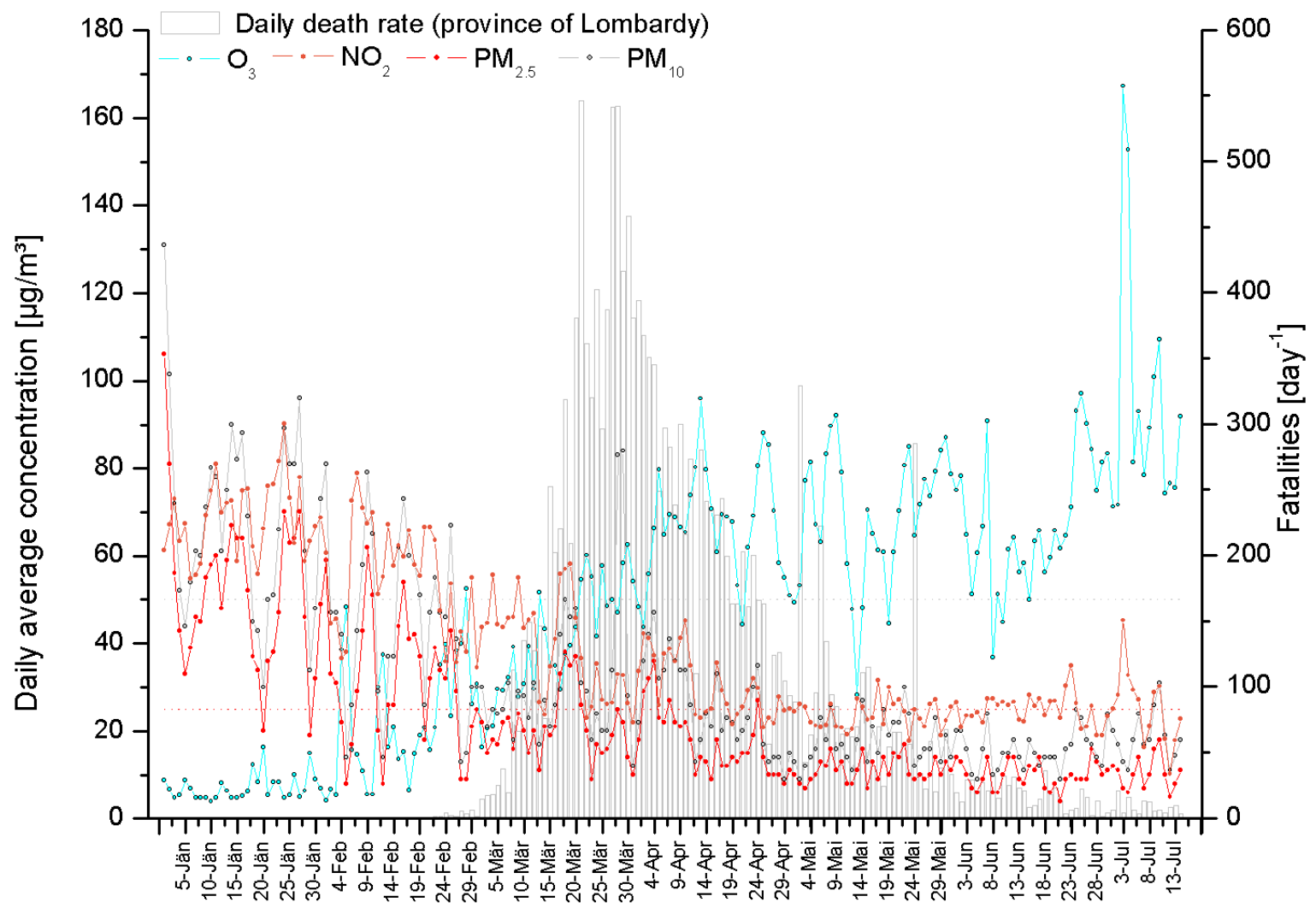

Date [dd.mm.'20]

Fig. 2. Daily average values of $\mathrm{NO}_{2}, \mathrm{O}_{3}, \mathrm{PM}_{2.5}$ and $\mathrm{PM}_{10}$ of Milan city for the first 5 months of 2020; $\mathrm{PM}_{2.5}$ and $\mathrm{PM}_{10}$ limits are highlighted as dashed lines in gray and red (APRA, 2020). The observed death rates include all fatalities documented within the wider Milan area (province of Lombardy).

corresponds to an increase in cardiovascular diseases by $0.4 \%$, whereas the daily mortality tends to rise by $0.3 \%$ (Vallero, 2014).

Regarding sulphur dioxide $\left(\mathrm{SO}_{2}\right)$, the threshold values of $350 \mu \mathrm{g} \mathrm{m}^{-3}$ were hardly reached even in urban hot spots such as Milan and usually fluctuated around a 1/10 of that threshold value (ARPA, 2020). Carbon Monoxide (CO) on the other hand could be an issue, however max $8 \mathrm{~h}$ average threshold levels of $10 \mathrm{mg} \mathrm{m}^{-3}$ are seldomly observed as during the colder months these oscillated at around 0.9 to $1.5 \mathrm{mg} \mathrm{m}^{-3}$ (ARPA, 2020).

In essence, the cocktail of toxic gases together with the aerosol loading do induce harmful health effects that in the short term are expressed as respiratory diseases (Babu et al., 2020). Coughing and wheezing are the most frequent complication of $\mathrm{NO}_{x}$ toxicity, but eyes, nose or throat irritations, headache, dyspnea, chest pain, diaphoresis, fever, bronchospasm, and pulmonary oedema are also common (Ghorani-Azam, et al., 2016). Accordingly, it is not surprising at all to see increased hospitalization due to elevated PM- and $\mathrm{NO}_{x}$-exposure among the elderly (age $>65$ years) and asthmatic prevalences among children (age $<8$ years) (Marino et al., 2015).

Long-term exposure to air pollution induces organismic wide effects, notably by inducing epigenetic changes (Madl, 2012). These become apparent through a lower quality of life, result in an earlier onset of diseases otherwise associated at a much later stage of life including premature deaths (due to ischemia and cardio-vascular as well as pulmonar mortality), and the induction of tumor progression (Benbrahim-Tallaa et al., 2012; WHO, 2012; Cesaroni et al., 2013).

Mortality attributable to long-term exposure to $\mathrm{PM}_{2.5}$, in 2015 was estimated to be around 4.5-4.8 percent of global fatalities amounting to $4.24 \times 10^{6}\left(3.70-4.78 \times 10^{6}\right)$, provoking higher mortality rates in polluted hotspots (Cohen et al., 2017). Particularly, mortality due to cardiovascular disease (specifically ischaemic heart disease and cerebrovascular disease) dominate the ranking (Bourdrel et al., 2017) for which a linear relationship associated to $\mathrm{PM}_{2.5}$ was found (Miller, 2020). 

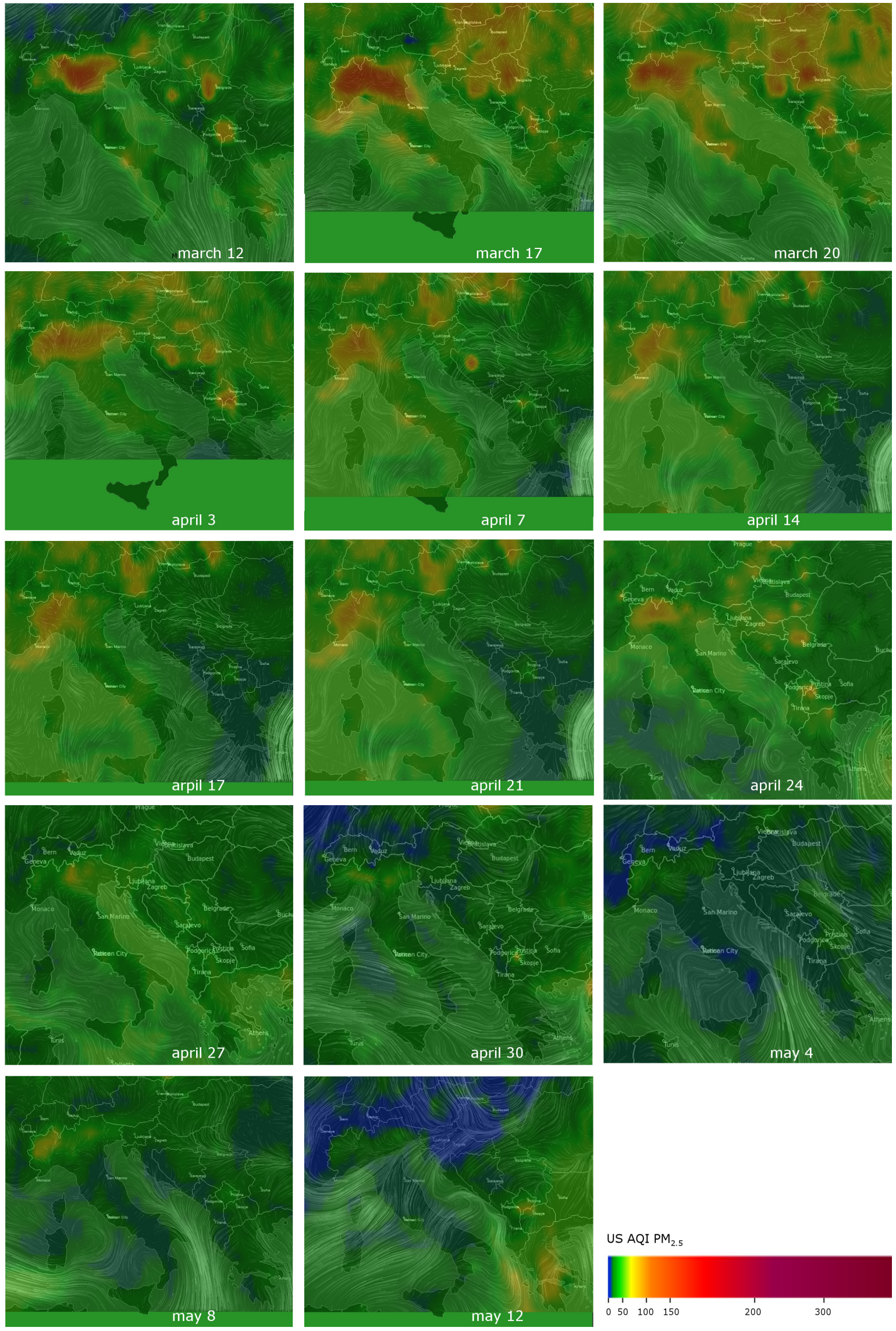

Fig. 3. Snapshots of the $P M_{2.5}$-inventory as modelled by the AQI-network covering a time frame from $12^{\text {th }}$ of March to $12^{\text {th }}$ of May 2020 (compilation based on AirVisual, 2020). 
Unfortunately, Italy is one of the EU member states still finding it difficult to comply with EU legislation on PM10 limits as outlined in the Directive 1999/30/EC (EU, 1999). Italy has also difficulties to meet the EU safety limits in the highly industrialized and densely populated area of the Po-Valley for $\mathrm{NO}_{2}\left(40 \mu \mathrm{g} \mathrm{m}^{-3}\right)$ and for $\mathrm{PM}_{2.5}\left(25 \mu \mathrm{g} \mathrm{m}^{-3}\right)$, according to the Directive 2008/50/EC (EU, 2008).

Consequently, Martuzzi et al. (2006) summarized that reducing $\mathrm{PM}_{10}$ to $20 \mu \mathrm{g} \mathrm{m}^{-3}$ could prevent 0.7 percent of documented cardiac-associated hospital admissions, 1.3 percent of respiratoryassociated hospitalizations, 31.7 percent of acute bronchitis cases in the $<15$ years age class and 1.7 percent of chronic bronchitis cases among individuals $>27$ years of age. Their report also states that not only 1259 days of bronchodilator use in children and $>800000$ in adults would be preventable, but also $>500000$ extra days of lower respiratory symptoms in children and nearly 8 million among adults. On top of that, almost half a million days of reduced physical activity, 6 million days of slightly reduced activity and the loss of nearly 2 million working days would be avoidable.

\subsection{Air Pollution Modulating Viral Virulence}

As evidenced by the presence of influenza-A strains during Asian dust storm events, the link between viral infections and elevated PM-concentrations is suspected since many years (Chen et al., 2010). Incidents of human respiratory syncytial virus (HSRV), known to cause pneumonia in children, surged during episodes of hazy conditions (Ye et al., 2016), so did the occurrence of measles cases in relation to $\mathrm{PM}_{2.5}$ concentrations (Chen et al., 2017), yet soared to 196 percent when elevated levels of $\mathrm{SO}_{2}$ were present simultaneously (Peng et al., 2020).

The colder season in general boosts the number of emergency visits mainly due to influenzalike illness (ILI) and severe acute respiratory infection (SARI) by a factor of five (Silva et al., 2014). So do daily $\mathrm{NO}_{2}$ averages correlate with peak virus season from autumn until early spring aggravating virus induced inflammations in the respiratory tract (Chauhan and Johnston, 2002). Indeed, exposure to hourly peak levels of $\mathrm{NO}_{2}$ up to $160 \mu \mathrm{g} \mathrm{m}^{-3}$ was associated with a significant increase in sore throat incidences, colds and absences from school, whereas higher levels of $\mathrm{NO}_{2}$ exposure, boosted rhinoviral infections as oxidant-dependent mechanisms triggered interleukin 8 (IL-8) production. In already debilitated individuals, pathogens such as human rhinoviruses (HRV) and HSRV resulting in acute upper and lower respiratory illnesses are readily identified in the vast majority of children ( $>80$ percent) and infants (up to 100 percent). Two Dutch papers reconfirmed this observation by showing that "atmospheric $\mathrm{PM}_{2.5}$ is a highly significant predictor for the number of confirmed COVID-19 cases" as well as "related hospital admissions" (Andree, 2020; Cole et al., 2020). The similarities with the Po-Valley are striking; both the Netherlands and northern Italy are engaged in intensive agro-industrial practices generating enormous amounts of ammonia, which in turn contribute to airborne PM-accumulation (MacRae and Russel, 1984; Stemmler et al., 2006, Zhang et al., 2009). Thus, the persistent exceedances of the legally binding $\mathrm{PM}_{2.5} / \mathrm{PM}_{10}$ threshold concentrations recorded within the second half of February (as highlighted in Figs. 2 and 3) and the number of cases infected by SARS-CoV-2 shown in Fig. 6 as of May 2020, resulted in the observed anomalous high frequency of COVID-19 incidents, which cannot be accidental, rather are in line with COVID-19-PM-variables found in Lolli et al. (2020). Such positive correlations are also documented for other air pollutants such as $\mathrm{NO}_{2}, \mathrm{CO}$ and $\mathrm{O}_{3}$ but less so for $\mathrm{SO}_{2}$ (Srivastava, 2020). With the exception of $\mathrm{O}_{3}$ (see Fig. 2), the implementation of a sharp lockdown did contribute to a drastic reduction in air pollution inventories, particularly $\mathrm{PM}_{2.5} / \mathrm{PM}_{10}$, carbon black, $\mathrm{NO}_{2}, \mathrm{CO}$, and VOCs (Srivastava, 2020). Beyond any doubt, we can say that prolonged exposure to air pollution is an inducer to chronic respiratory diseases even in young individuals and given the fact that a 1 unit increase in $\mathrm{PM}_{2.5}$ provoked an 8 percent increase in COVID-19 fatality rate (Perone, 2021) and a 1 ppb increase in $\mathrm{NO}_{2}$, correlated with a rise in COVID-19 incidents by 0.462 (Suhaimi et al., 2020), should have alarmed authorities beforehand.

Although viruses are essential and dominant players in microbial ecology (Villarreal, 2005; Ryan, 2009; Moelling, 2017; Sole and Elena, 2019), fairly little is known about relevant patho-physiological threshold levels, possible sources, modes of transformation, and their fate in the lower troposphere. Prussin et al. (2015) investigated the total airborne concentrations of virus-like and bacteria-like particles in various locations of outdoor vs. indoor air and found them to be 2.6-1.6 times higher outside than inside. Yet, this is no indicator for their virulence, as was witnessed during the 
developments aboard the cruise ship Diamond Princess, resulting in 619 reported fatalities, which according to modelling efforts, could have stabilized to 76 cases if an early evacuation would have been enforced (Rockloev et al., 2020). In a similar incident in GuangZhou (China) a group of diners at a restaurant became infected by SARS-CoV-2, yet neither the waiters nor the other guests present at that time contracted it (Li et al., 2020b). As with the cruise ship Diamond Princess, infection was promoted via a stationary "air-recirculation envelope" that was absent for the other tables.

The most probable route of transmission (next to hand-shake, or surface cross-contaminations) are aerosolised droplets produced by sneezing, coughing and speaking - with the latter being rather modest as it amounts to only 50 particles second ${ }^{-1}$ measuring 3-5 $\mu \mathrm{m}$ in diameter; only nose breathing accounts for even lower aerosol production rates (Hadei et al., 2020). Individuals acutely infected with influenza harbour approx. $10^{9} \mathrm{~cm}^{-3}$ viral particles in their blood stream upon which about $10^{4}$ aerosolized viruses are released by coughing or sneezing (Yan et al., 2018). These aerosols are 4-8 $\mu \mathrm{m}$ in size and are easily distributable via a fan. Hadei et al. (2020) documented a bimodal distribution of sneezed aerosols with diameters around $74 \mu \mathrm{m} \mathrm{GMD}$. While the finer fraction can remain airborne for $90 \mathrm{~min}$, smaller ones do so for up to $30 \mathrm{hrs}$ (Duguid, 1946; Loudon and Roberts, 1966; Xie et al., 2009). Viability tests for SARS-CoV-2 under lab-conditions though have revealed that they can remain airborne and infectious for up to three hours - when adsorbed onto surfaces even for days (Doremalert et al., 2020), thus, providing further evidence that airborne transmission of human viral diseases are essentially indoor events (Couch, 1981; Ahlawat et al., 2020; Moelling and Broecker, 2020). Virulence under outdoor conditions is quite short-lived as the corresponding have a half-life amounted to only 15-30 mins. Most of the deactivation is attributable to the $254 \mathrm{~nm}$ UV-light present under daylight condition, which in indoor-environments is usually absent (Harm, 1980).

An investigation performed inside a US-clinic using a growth tube collector (GTC) designed to sample airborne microbes (Pan et al., 2015) revealed that both the samples as well as the transfer and culturing in Vero cells tested positive for SARS-CoV-2 (Lednicky et al., 2020). Yet interestingly, SARS-CoV-2 was found to be harmless in comparison to three other human respiratory viruses (Influenza-A H1N1, and H3N2, as well as Human Coronavirus OC43) identified in the sample batch-these three strains were found to induce cell-death. This finding is relevant in terms of data interpretation and could indeed lead to completely false allocation of the viral vector. It also fuels existing concerns by which a low number of performed SARS-CoV-2 tests coupled with a low rate of infection can result in a large erroneous positive predictive value (see supplement on PCR-reliability). Indeed, studies published on RT-PCR performance, provide clear indications that caution should be used in the interpretation of false-positive/-negatives (Kucirka et al., 2020; Watson et al., 2020).

With regard to studies on the spread of virus and long-term air pollution, there is solid literature evidence that correlates the frequency of viral infection cases with atmospheric $\mathrm{PM}_{2.5} / \mathrm{PM}_{10}$ concentrations (Ciencewicki and Jaspers, 2007; Sedlmaier et al., 2009). Infectability of airborne PM-droplet-virus aggregates depend heavily on ambient conditions; while elevated temperatures and solar radiation have a positive effect on the virus inactivation rate. In warmer indoor environments with low relative humidity levels ( $<40$ percent) as compared to outside, viral spreading is facilitated due to droplet shrinking resulting in longer residence times (Ahlawat et al., 2020). Under such conditions, dehydration stress of the epithelial lining coupled with longer residence time of SARS-CoV-2 facilitate airborne transmission. Humidity levels in the physiological range seems to have little effect on the viability of SARS-CoV-2. Higher levels (<90 percent) on the other hand can promote the opposite, by increasing viability and thus resulting in a higher rate of virus spread (Despres et al., 2012). Only very elevated $\mathrm{rH}$-levels ( $>95$ percent) seem to induce a mitigating effect on viral virulence due to hygroscopic growth of the virus-laden droplet (Feng et al., 2020).

Sajadi et al. (2020) investigated the role of meteorological conditions in the spread of the SARSCoV-2 by comparing events among 50 cities - including Milan (ITA) and attested that climatic conditions influence viral transmission in synchrony to other seasonal viruses. Although seasonal patterns do not stop the spread of SARS-CoV-2 altogether, Xu et al. (2020) modelled that the northern hemisphere summer would lead to a 10-15 percent reduction in the risk of transmission with an inversion of the trend once the northern hemisphere flips back into winter. Bhattacharjee 
(2020) reported that higher temperatures correlate to lower confirmed COVID-19 cases in cities of the Po-Valley such as Bergamo, Brescia, Cremona, Lodi and Milan; whereas an increase in humidity - as observed during the colder months - showed an opposite trend - with the city of Lodi emerging as the only exception.

Some studies investigating the "Trojan-horse" effect of particle-droplet aggregates found interesting correlations. The bulk of adsorbed biological material during smog events varied widely and can range from 95.45 percent on $\mathrm{PM}_{10}$ and 93.04 percent on $\mathrm{PM}_{2.5}$ for bacteria and 4.52 percent on $\mathrm{PM}_{10}$ and 2.80 percent on $\mathrm{PM}_{2.5}$ for viruses (Qin et al., 2020). This changes drastically during severe smog events; i.e., 80.8 percent for $\mathrm{PM}_{10}$ and 86.1 percent for $\mathrm{PM}_{2.5}$ bacterial loading and 0.1 percent viral for both PM-classes (Cao et al., 2014). Yet in the latter, the human adenovirus $\mathrm{C}(\mathrm{AV}-\mathrm{c})$ was identified, which is known to cause upper and lower respiratory tract infections among children. Similar correlations of chronic exposure to atmospheric contamination and spread of SARS-COV-2 were observed in 71 Italian provinces (Fattorini and Regoli, 2020).

Despite the highly variable prevalence of single viruses, the overall occurrence of a viral respiratory infection among patients with a pre-existing respiratory disease, even with a normal influenza outbreak, is relatively stable over time and typically peaks during the cold season (Fig. 4).

As Fig. 4 suggests, Coronaviridae have been around for quite some time. First reports about the existence of this class of viruses date back to 1965, which prompted Tyrrell et al. (1975) to tentatively group them as a separate taxonomic entity. Since then, widespread distribution of coronaviruses in common cold was particularly associated with cold and sniffles among young children (Myint, 1995; Gaunt et al., 2010). This may indicate cross-reactivity of these viruses between the immune repertoires associated with a common cold and implies that a significant proportion of the population may be relatively immune to COVID-19.

\subsection{Initial Dynamics of the Unfolding COVID-19 Crisis in Italy}

At a first glance, the global dynamics as documented by the COVID-19 data-hub (Gardner et al., 2020) would make apparent the seriousness of events, yet some questions on the methodology on

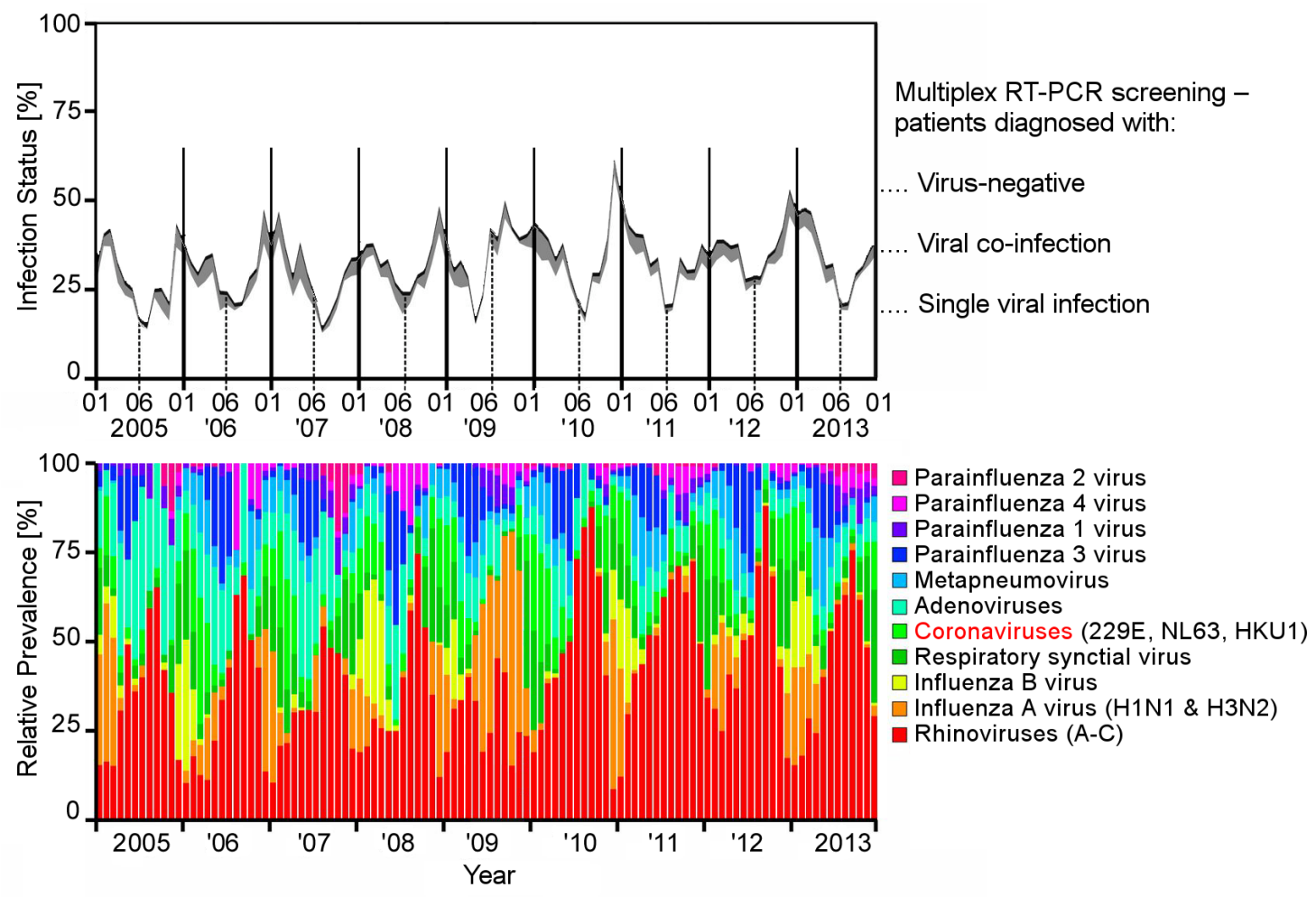

Fig. 4. Bands denote the ratio of viral isolates obtained in Houston during two-week time periods from Nov. 1990 to May 1993 (Figure modified from Nickbakhsh et al., 2019). 
data collection and processing need to be raised first. When considering that previous influenza outbreaks with slightly lower intensity only reached moderate attention by politicians and media alike, one remains struck how sensationalism and panicking has set in over the last few months. No distinction was and is still made between cases infected with SARS-CoV-2 but symptom free and suffering from COVID-19 symptoms. Initial estimates assumed that 40-70 percent of the world population will be infected, which was later on revised to 20-60 percent (Ioannidis, 2020). Likewise, an exaggerated case fatality rate (CFR) was proclaimed to reach 3.4 percent (WHO, 2020c).

Consultation of actual data accessible from the European Centre for Disease Prevention and Control (ECDC) reveals a somewhat different situation in overall mortality (EuroMomo, 2020). Regardless of the cause of death, excess mortality during the first wave was observed only in some of the listed 24 countries, primarily in the age group of $65+$ years, while other states even fell below the long-term trend.

Fig. 5, displays a composite plot of the first wave during winter-spring 2020 in which higher mortality is grouped in opposition to those with lower or normal mortality rates. Together with the age-specific mortality pattern of Italy it is possible to objectify the intense media attention about COVID-19 as these data represent all mortalities, regardless whether an individual died with or as a result of a SARS-CoV-2 infection. Furthermore, this figure makes evident that only the stratum of people $>65$ yrs is of particular interest. Consulting the official Italian data-hub of the working group (ISS, 2020a) provides additional confirmation. Fig. 2 of the May-report (ISS, $2020 b)$ clearly shows that the most affected group are found in the respective age-slot of 8089 yrs, totalling 12,729 out of 31,096 overall deaths observed till compilation of the reporttogether with the fatalities observed within the age group of 90+ (additional 5,227 fatalities) amounted to 57.74 percent. Listed therein are also the most common comorbidities, which states that fatalities in the no-comorbidity group amounted to just 4.1 percent (quite similar to those found in the US, with only 6 percent of the fatalities solely attributable to COVID-19 (CDC, 2020b)), whereas the rate steadily increased to 15.0 percent with a single comorbidity, 21.4 percent with two, and 59.6 percent with three or more comorbidities.

Regional differences of SARS-CoV-2 infection cases are displayed in Fig. 6, as diagnosed by regional reference laboratories $(n=227,204)$. The southern regions as well as the islands reported a lower number of cases than the northern-centermost regions. Incomprehensively, Italian authorities did not discriminate among regions of high and low incidents, but imposed the complete shutdown onto the entire country.

With respect to the fatalities observed, the actual rate in a given age group associated to a
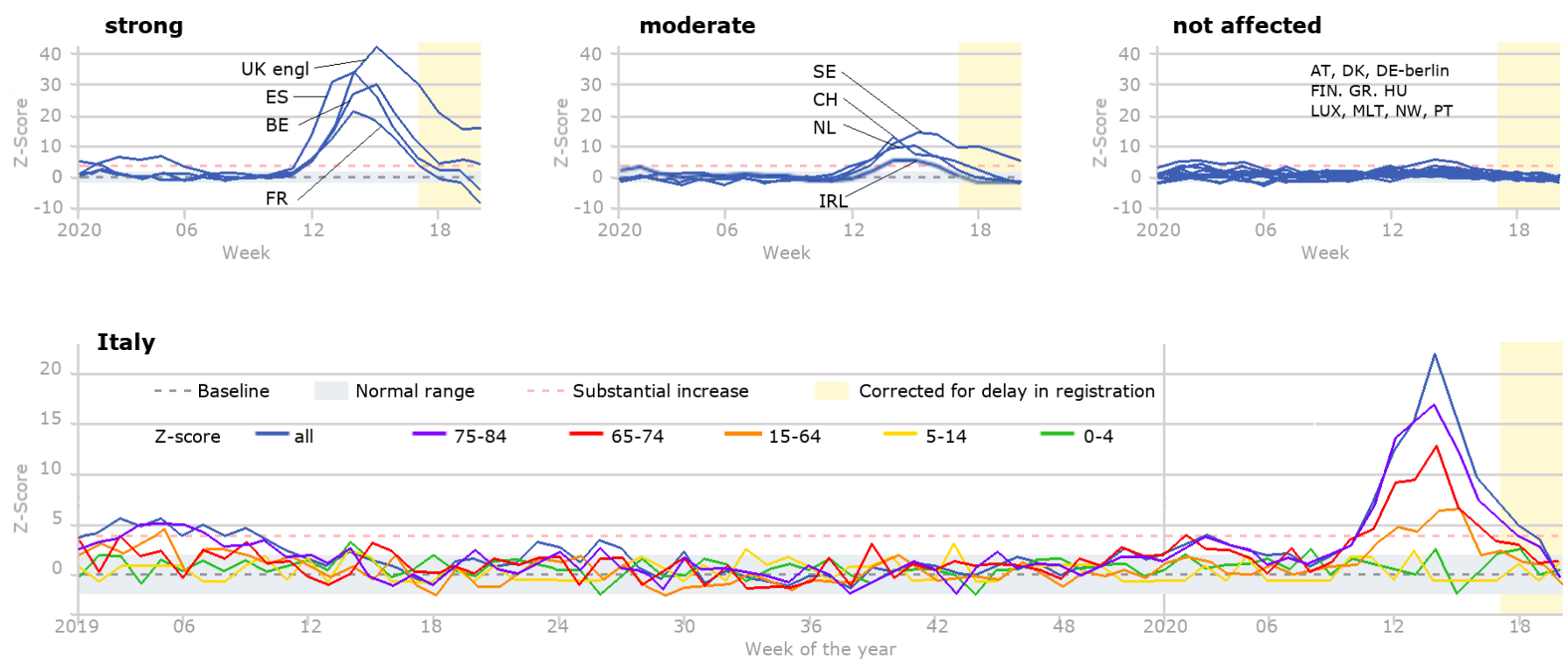

Fig. 5. Weekly mortality z-score of Italy (bottom) vs other participating countries (top) covering week 1, 2019 until week 21 , 2020; bottom part shows the most affected age groups (Figure modified from EuroMomo, 2020). 


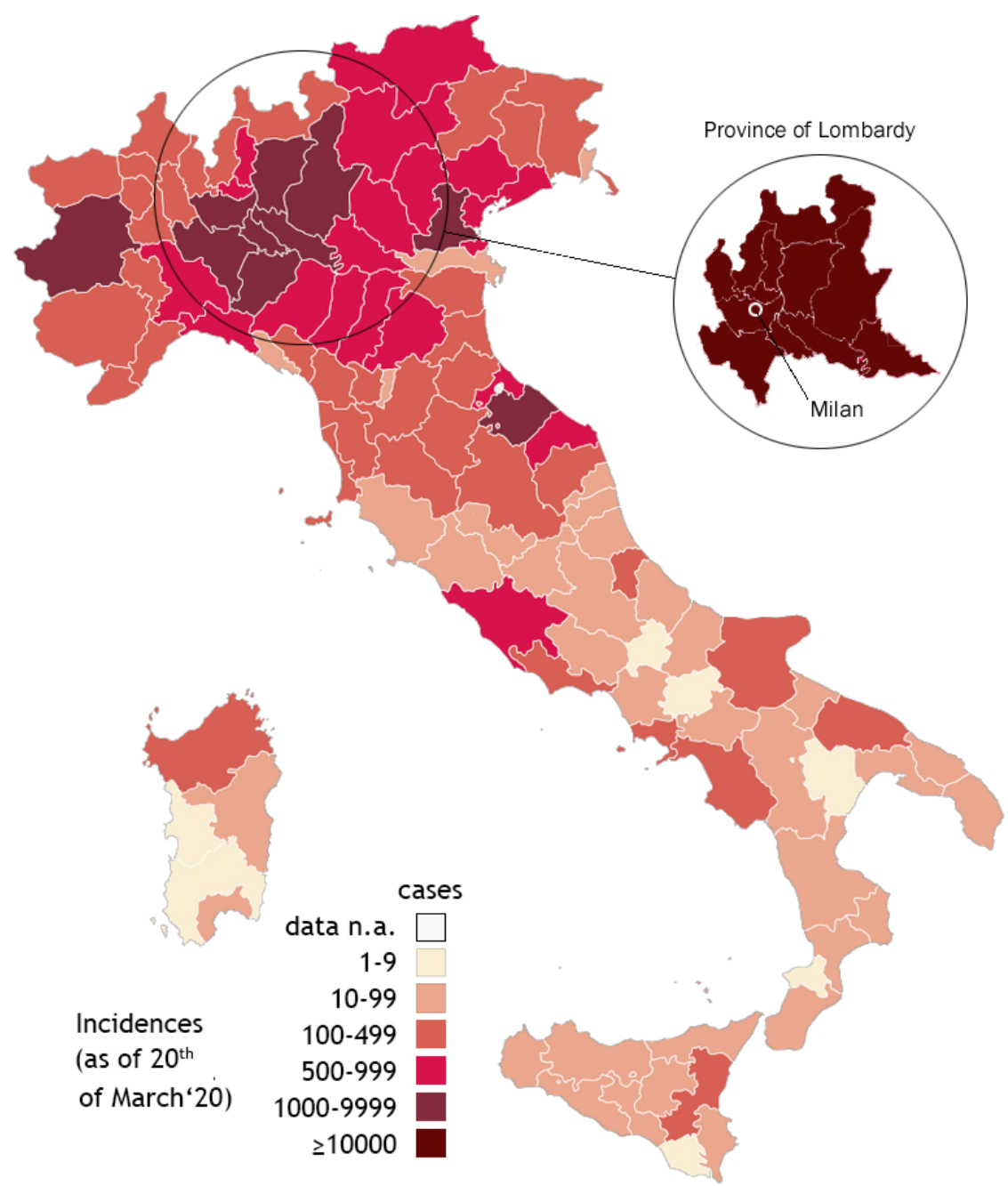

Fig. 6. Italian Covid "hot-spots" incidences as diagnosed till $20^{\text {th }}$ of May (map based on data obtained from ISS, 2020b).

SARS-CoV-2 infection is much lower than the data that circulated in the media suggested. Based on May $22^{\text {nd }}$ data, loannidis et al. (2020) calculated COVID-19 fatalities in the age group < 65 yrs to be around 2.7-11.2 percent and for the stratum 65-79 yrs 13.5-48.8 percent among 11 European countries. The lion-share within the EU however of all deaths attributable to persons aged $\geq 80 \mathrm{yrs}$ ranged from 43.8-79.2 percent. This number is well in line with the Italian ISS-data stated above (57.74 percent). A recalculation of documented data is shown in Fig. 7 and highlights the fatalities observed in Italy over the first 7 months during which the COVID-19 crises peaked. Hence even within the most hard-hit age group ( $>80 \mathrm{yrs}$ ) fatalities amounted to around 4.5 individuals for every 1,000 inhabitants. Consequently, for a hotspot area such as northern Italy, the rather moderate share attributable to COVID-19 fatalities in relation to other diseases prevalent in that age group is striking and is very much in agreement with results published by loannidis and co-workers, according to which the absolute risk of death, even in this age class, hardly reached $\sim 1.75$ percent in the most hard hit epicentres and $<1 / 1,000$ in other provinces (Ioannidis et al., 2020).

\section{PART-II A LOOK BEYOND SARS-COV-2 AND AIR POLLUTION}

\subsection{Immuno-pathogenesis of SARS-CoV-2 and Implications for Vaccines}

Based on the above evidence, the connection between long-term air pollution resulting in an excess stress-burden for susceptible individuals cannot be denied any longer. A chronically irritated epithelial lining is thus a gate-way for potential infections. To understand the biodynamics of 


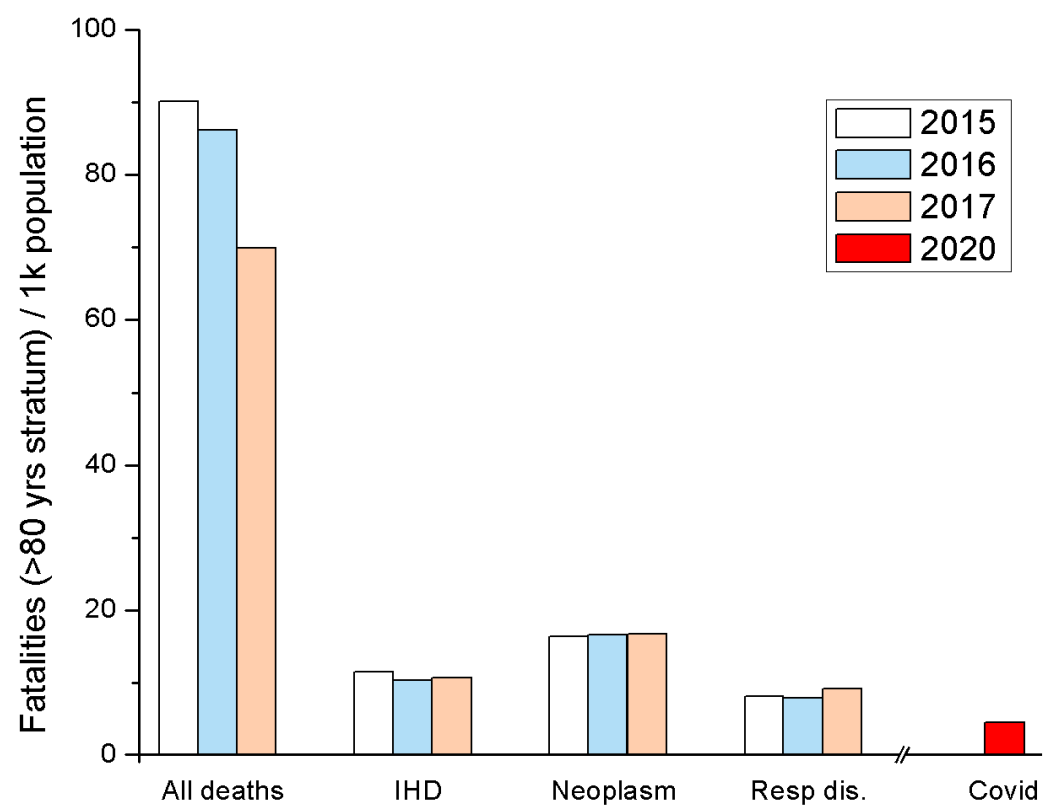

Fig. 7. SARS-CoV-2 infection associated deaths in relation to respiratory diseases, tumour incidents, IHD and total death rates for the most affected age groups in Italy ( $\geq 80$ years per thousand inhabitants for the first 7 months of 2020). Data based on Eurostat (2020a, b) and ISS (2020b).

SARS-CoV-2, and why the rush to find a quick fix on the viral front rather than on the pollution front deserves a few words about some viral-sphere associated characteristics.

Virulence of SARS-CoV-2 has been allocated to the small envelope protein (E), which induces SARS in humans (for bio-molecular details of coronaviruses see King et al., (2011)). It has a strong affinity to cells in the lower respiratory tract, where it replicates, resulting in infections, which occurs in three distinct phases:

(i) mild disorder with symptoms restricted to the upper respiratory tract.

(ii) non-life-threatening pneumonia; or pneumonia with acute respiratory distress syndrome (ARDS) that commences with light symptoms that persist for 7-8 days, which sometimes lead to rapid deterioration and ARDS requiring medical intervention (Heymann and Shindo, 2020). However, individuals $<65$ years of age have a rather low risks of developing a lethal form of the SARS-CoV-2 infection.

(iii) complications due to neuro-invasive capacity of SARS-CoV-2 (Li et al., 2020a), with neurologic symptoms occurred in 36.4 percent of documented cases (Mao et al., 2020) —including alterations in smell and taste (Spinato et al., 2020). More dramatic effects concerned cardiac and arrhythmic complications (Kochi et al., 2020) in 44.4 percent of ICU-treated patients (Lazzerini et al., 2020) leading to higher in-hospital mortality risks (Shi et al., 2020). Autopsy on deceased elderly patients (median age 73 yrs) diagnosed with SARS-CoV-2 revealed thrombo-embolism in 58 percent of cases (Wichmann et al., 2020) whereas pulmonary thrombosis was diagnosed in 71.4 percent of cases (Marongiu et al., 2020; Tang et al., 2020).

The family of single stranded RNA (ssRNA) viruses - to which SARS-CoV-2 belongs-has peculiar properties as it strikes with an enormous genomic flexibility on one side as well as species-specific persistency on the other; i.e., genetic stability and their ability to co-evolve with their host cells. Under lab-conditions, these viruses generate different gene populations in rather short periods of time. Under natural conditions and without artificial disturbance however, they tend to maintain rather homogeneous populations with molecular clocks being much slower than those observed among acute viruses (Villareal, 2005). Nonetheless, SARS-CoV-2 mutates constantly and genetic analyses performed six months after first-case reporting, differ from analyses carried out at the beginning, with the most prominent alteration regarding a specific modification in the spikeprotein, called D614G (Zhang et al., 2020), with new variants popping up continuously ever since (CDC, 2021; ECDC, 2021). 
While mutations concern one aspect, quasi-Species consortia (qS-c) represent another. Behavioral motifs of cooperative RNA-agents are the drivers behind basic viral skills, which are responsible for the synthesis of de novo nucleotide sequences; i.e., inserting, changing or deleting sequences of host sequences (Villarreal and Witzany, 2013; Villarreal, 2015). This means that for "every variant" (1) a given nucleic acid sequence does not maintain a unique position but rather depends on the contextual usage; which in turn implies that (2) the nucleotide sequences follow real-life conditions that aren't randomly arranged. The far-reaching effects of such variations are drastic as viral qS-c populations are highly diverse and it is assumed that no two genomes therein reveal identical sequences - even if a cloned, genetically homogeneous template is used to trigger a cycle of infection (Villarreal and Witzany, 2013).

There is even a third aspect, that concern particularly human endogenous retroviruses (HERV) fulfilling crucial life functions (Villarreal, 2005); i.e., the non-coding retroviral RNA sequences within the human genome are responsible for editing tasks. Phylo-ontogenetically speaking, this feature accounts for crucial competences such as "replicase, polymerase, integrase, DNA-repair, restriction/modification, methylation, eukaryotic nucleus, division of transcription and translation, nuclear pores, tubulin-based chromosome duplication, innate immune system, adaptive immune system, cartilage, bones, skin, mucus, milk, placenta, viviparity" just to name a few (Witzany 2006). Why does this matter? It matters as at least two of the ongoing vaccine platform developments use RNA and DNA technology (Lurie et al., 2020) and according to Lyons-Weiler (2020) reveal immunogenic epitope similarities of SARS-CoV-2 with homologues to human proteins. About a third of the potentially targeted human proteins (putative autoantigens) are key players in the adaptive immune system. Thus, a potential RNA-vaccine could generate a series of possible side effects. These epitopes ought to be excluded from potential vaccine developments currently under way to reduce autoimmunity reaction. Yet, all genetic vaccines target the human protein biosynthesis aiming to manipulate the RNA translation at the ribosomes in order to induce the production of viral proteins as antigens, usually spike proteins - see also vaccine package leaflet (WHO, 2021). Given these factors, documented side effects of the current vaccination campaigns using RNA-technology pop up regularly (Coors et al., 2005; Jackson et al., 2020; Cabanillas et al., 2021; deVrieze, 2021). As a consequence, candidate vaccines with granted emergency use designation should not be deemed to have established a standard of prevention in the settings they are introduced to (Singh and Upshur, 2020).

Fortunately, evidence so far does not yet support speculations that the implementation of "genetically modified" vaccines might interfere with the target cell's genome, which could lead to activation of oncogenes or deactivation of anticarcinogenic gene sequences and therewith increased in cancer risk (Ura et al., 2014; Aubrit, 2015; Hasson et al., 2015). This undesirable "Trojan Horse" effect must be taken seriously since the transferred nucleic acids are designed to mimic human genes to allow integration into human protein biosynthesis. This could potentially lead to uncontrolled integration mechanisms. Critics of genetic vaccines therefore point out that any shortenings of clinical evaluations for the development of a vaccine against COVID-19, especially when based on the transduction of nucleic acids, would be a violation of the precautionary principle (Arvay, 2020; Jiang, 2020). This adverse potential arose as the source material for vaccine production uses animal cell lines in-vitro. Such modified "designer cell lines" (derived from duck, monkey, dog tissue and human embryonic kidney cells, known under brand names like EB66 $\AA, A G E 1 . C R \AA$, PER.C6 $\AA$, HEK 293, etc.) are used for the production of novel influenza vaccines not only induce ethical questions, but could unleash a Pandora effect (Hsee and Ruan, 2016). Hence, this particular field urgently needs further research as so-called "chromosomal insertion" are known to happen to a certain extent, or can take place as an undesired side effect (Baum et al., 2006).

This immediately raises the question of vaccination efficiency (VE), which often is found to be age-dependent. VE for the prevention of laboratory confirmed $A(H 1 N 1)$ and $A(H 3 N 2)$ influenza cases turned out to be even negative for some age-groups (Buda et al., 2019). Fig. 8 depicts such an exemplary trend. A negative VE-values means that no statistically significant protection of the vaccinated individual against influenza can be demonstrated compared to unvaccinated people; i.e., implying that vaccinated persons have a higher risk of contracting influenza at the same exposure conditions than unvaccinated individuals.

Although it is far too early to evaluate the ongoing vaccination campaign, it seems there is a trend that this novel line of vaccines results in higher fatality rate particularly among the elderly 


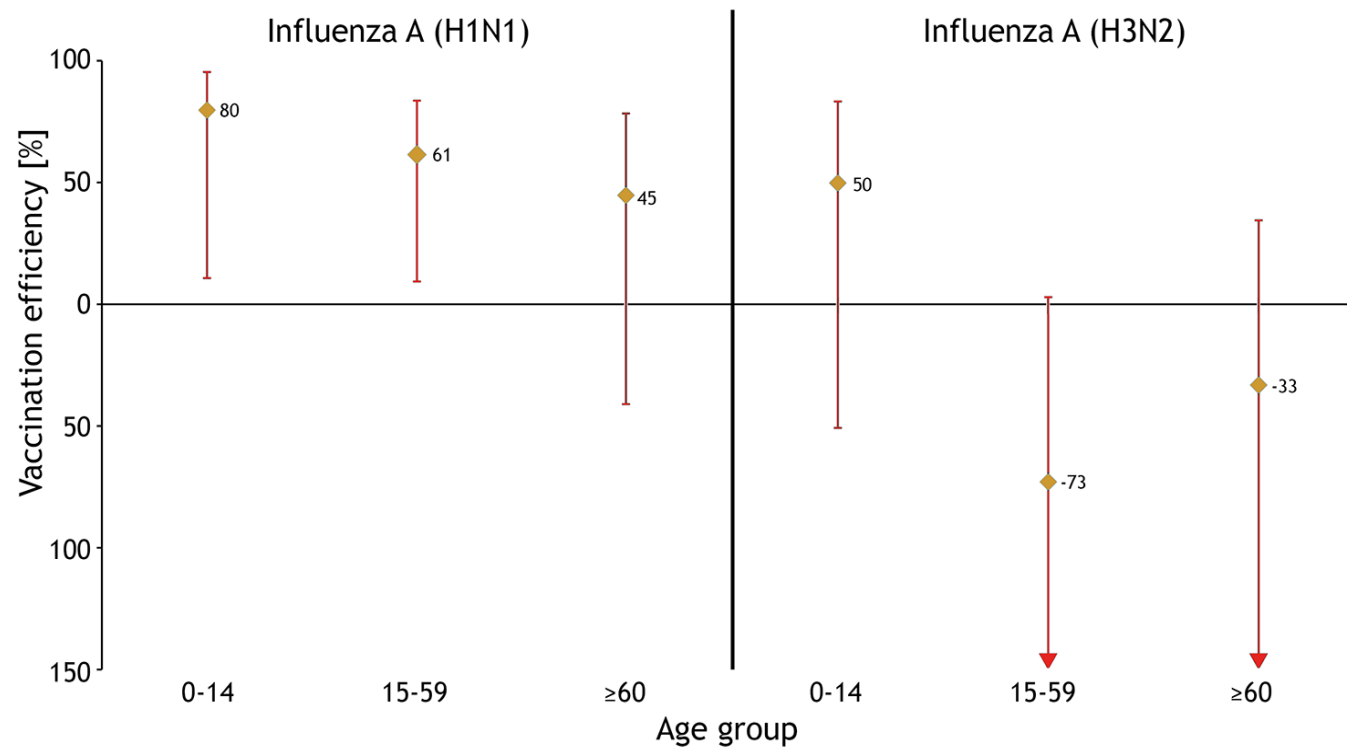

Fig. 8. Estimation of the effectiveness of influenza vaccination against influenza $A(H 1 N 1)$ and influenza $A(H 3 N 2)$ in three age groups in the $2018 / 19$ season, based on a point estimate and a 95 percent confidence interval. The arrowheads indicate a value outside the $y$-axis shown (Figure modified from Buda et al., 2019).

in comparison to conventional influenza vaccines (VAERS, 2021). While vaccine efficiency is still being evaluated, we can't exclude in the long run that vaccination will fail altogether due to continuously mutating subspecies. From this perspective, mass vaccination does not make sense at all as a large part of the population is already sufficiently protected by natural infections (Reiss and Bhakdi, 2020). Even Gomes et al. (2020) come up with the assumption that people who have good natural immunity are not susceptible to the virus and therefore do not become sick. Rather, by realistically modelling available data, a maximum of 7-18 percent of the population will become infected with SARS-CoV-2, implying that herd immunity is achieved already at that level. Relating these aspects to the hypothesized claims that it will result in outstanding numbers of fatalities, it is further corroboration that that SARS-CoV-2 is not the "deadly" virus as initially proclaimed, as in the vast majority of cases it did not even lead to severe illness and/or serious sequelae in healthy individuals. Therefore, the need to receive a SARS-CoV-2 jab is uncalled for (Reiss and Bhakdi, 2020). We should not forget that any vaccination is an "artificially induced infection" immediately affecting the entire organisms, thus sudden rather than sigmoidal as in natural infections, and does not act at the site of the infection (nose, throat, lungs). In other words, even vaccinated individuals still will act as potential "spreaders" of SARS-CoV-2.

Nonetheless, several governments within the EU still regard and thus recommend vaccination for the age group of $>65$ years (EDCD, 2018), with Italy being no exception. Some 20.3 percent of the residents in the COVID-19 hotspot province of Bergamo (the provincial capital lists 120,287 inhabitants, the entire 1,109,933 inhabitants) are $\geq 65$ years (Comuni Italiani, 2020). For the 2019-2020 season 185,000 doses of influenza vaccine have been ordered by the Bergamo authorities to offer free vaccination for individuals in this age group (Bergamo News, 2019a). In the same period some 34000 inhabitants of Bergamo and Brescia have undergone meningitis vaccination (Bergamo News, 2019b), even though it is known that meningitis vaccination is associated with complications when performed in individuals showing flu-like symptoms (Wood et al., 1995; Liu et al., 2017). Such adverse effects are not new and have been documented on several occasions (Cowling et al., 2012; Wolff, 2020). Hence, Italy is among those EU-member states with a vaccination rate in that age group exceeding 50 percent (i.e., 52.7 percent) for the past 2019 flu-season (Eurostat, 2020c) — only Spain, Belgium, Ireland, the Netherlands and the UK rank higher and have likewise been hit hard during the first COVID-19 wave. In fact, a preprint article relating COVID-19 incidences to vaccination coverage rates (VCRs) shows exactly that (EBMPHET, 2020). Therein, the UK, the Netherlands, Belgium, Spain and Italy (among others) 
reveal a statistically significant $(p<0.05)$ positive correlation between VCR and incidence, as well as mortality of the population aged 65 yrs and older. Similar correlations between VCR and case fatality rate (CFR) for Europe have also been identified. In accordance Doshi, the editor if BMJ (2020a, b) the problems associated with current genetic vaccines and the elderly have been properly addressed: (i) none of the vaccine trials is designed to achieve a significant reduction in hospital admissions, intensive care unit treatments, or deaths; he further states that ii) in the absence of sufficient data in the over- 65 group, implies that people $>65$ should not receive these vaccines. Hence, we are prompted to ask the question about the usefulness of these vaccines and why are these vaccines being pre-financed and produced with horrendously high government funding but leaving the rights in the ownership of companies that have been called for in the development of theses vaccines?

\subsection{SARS-CoV-2 and the Wider Implications}

In essence, COVID-19 is not the pandemic of the century with millions of postulated deaths. However, "exaggeration and overreaction" have badly damaged the image of science, public health, media and policymakers alike. The widespread application of lockdowns across Europe fostered disbelief and jeopardized the chances of an appropriate response in the event a real pandemic emerges (Ioannidis, 2020). Given the harsh reactions by the Italian and other EUgovernments alike, we agree with Remuzzi and Remuzzi (2020) that the most effective way to contain a virus outbreak among EU member states is to avoid close contacts at an individual level, and implement strategies that focus on protecting high-risk elderly (Ioannidis et al., 2020).

Unfortunately, the excessive alarmism generated over the past months, as well as the recent push towards rapid vaccination as the only proclaimed solution induced additional collateral damage on several fronts. The first front concerns the reluctance to address life-style issues, eating-drinking-, smoking habits etc. to implement immune-enhancing strategies on a personal level. The second would embrace the full spectrum of non-allopathic medical treatments to boost resilience among those groups affected most by the current health crisis. None of the above has been implemented on a large scale, leaving the public to believe that we are in an absolute state of emergency and receiving the "jab" is the only escape route available. Persistent governmental pressure, the ongoing curfews and personal restrictions, already show repercussions on the psychological level, which addresses the third front (BRF, 2020; Pirkis et al., 2020). By now, susceptible individuals show all the signs of post-traumatic stress disorders that are so well described in the field of Psycho-Neuro-Immunology (PNI). Unfortunately, mainstream allopathy has put the attention solely at SARS-CoV-2, its mechanisms of infection, without considering that humans are much more than just a body infected with a virus. As PNI embraces a holistic vision of medicine, it warns us about the adverse effects of persistent stress loadings, with children being the most susceptible group (Swartz et al., 2016). Since stress exposure of this kind is known to modulate a person's epigenome, it correlates with the observations made within the field of PNI that such multiple stress exposure at a young age will have life-long effects (Gapp et al., 2017). The ongoing psycho-terror traumatizes children and without treatment may result in a loss of life-expectancy up to three years, will statistically sooner fall victim to chronic diseases and in case of repetitive adverse child experiences, such as emotional abuse, domestic violence, sexual abuse, will result in a two-decade shortened life expectancy (Schubert, 2016; Schubert personal communication). Since these consequences will only be seen in decades to come, it is simply outrageous that for over a year now, current allopathic medicine, still acts out entirely mechanistically.

At a social level it is unfortunate to witness that the entire dynamic has taken an autonomous course, leading to the suspension of the visa-free Schengen zone, promoting nationhood-mentality of member states via border closures that culminated in a total lockdown. Yet all it has proven so far is that these measures were not able to prevent COVID-19-related fatalities (Walach and Hockertz, 2020).

At the global scale, the COVID-19 crisis mirrors on how humanity endeavours on this planetvery much in the sense of the Hardin's original worries expressed in his Science article: "The tragedy of the commons" (Hardin, 1968). It is therefore not daring to claim that the current emergency puts a dominating 3000-year-old cultural blueprint and its image of mankind at stake; the logic of growth, conquest, domination and exploitation has indeed reached its limits. In the global 
context, survival can no longer be achieved through domination, competition and survival of the fittest but exclusively through cooperation — both politically as well as economically.

Therefore, recent events must be seen as an incentive to rethink ongoing neo-liberal practices and to enforce a radical change in which environmental protection, social justice, human rights are not just words of paling ink written on fading paper but incorporated into morality and enforced by legislation as requested by Hardin. We have to acknowledge that the Anthropocene and with it the changing image of mankind needs to be aligned to a collective survival strategy. Unlike man as the "crown of creation", Homo sapiens of science-particularly in the field of bioscience - is not above nature, but part of and always interwoven with it. Survival cannot be a question of domination, a fight against "something", but must practice and negotiate intelligent coexistence. We no longer can therefore allow a loose-knit group of high-level experts, with far-reaching political connections, to run efficient campaigns to deceive the public and ignore well-established scientific knowledge (Engelbrecht and Köhnlein, 2007; Oreskes and Conway, 2010).

While lobbying is one aspect, an expert panel in times of crisis is another. Past generations of scientists had a much broader standing on given issues by looking at the challenges from a "generalist" perspective. The current generation of scientists has undergone a sort of self-censorship by limiting themselves to a specialists' perspective, often avoiding the multi-discplinarity research questions bring about. This has huge implications for state authorities in the quest for expert advice to design and implement an appropriate response strategy. However, none of the expert panels as we are aware of mirror that complexity but as the past months have shown reflect a tiny slice only, leaving authorities partly in the dark during difficult decision-making processes. Consequently, and given the severity of the recommendations that followed thereafter, a compact panel consisting only of selected expert can only be but insufficient, just as a poem written with only a few letters of the alphabet is unable reveal the deeper meaning of the poet's intention. In order to provide a comprehensive evaluation of the situation to state authorities, a panel of experts must be composed of representatives that cover all scientific disciplines. Only then will policy makers be capable to navigate us safely and with delicacy through this crisis.

Such a larger body of expert came together during the WEF-meeting later last year, which prompted the EU-commission to initiated the "Great Reset" (Schwab and Malleret, 2020). This initiative seeked new ideas to catalyse a new approach on how our societies should be run and proposed a reset on the Economic, Societal, Geopolitical Environmental and Technological front. In doing so, four important building blocks have been addressed to make this happen: i) Change our mindset-if we made it up once, we can make it up again; ii) Create new metrics-measuring what matters will change everything; iii) Design new incentives-you get what you pay for; iv) Build genuine connection-distance is the danger (Sutcliffe, 2020). In fact, a recent study did indeed show that as a result of the ongoing SARS-CoV-2 dynamics, greenhouse-gas emissions plummeted significantly (LeQuéré et al., 2021), just as $\mathrm{NO}_{2}$-emisisons across Europe dropped drastically during the first months of 2020 (ESA, 2020). But more would be needed if the global community aims to reach the target goal (limit global warming to well below 2, preferably to $1.5^{\circ} \mathrm{C}$, compared to pre-industrial levels) as agreed during the Climate agreement in Paris (UN, 2015). While the "Green Deal" as part of this agenda may sound as a move towards a more sustainable society, it completely is in opposition with the intended enforcement of globalization, the push ahead of the digital society, particularly digital vaccination passport (Reuters, 2021) and ultimately the aim to mass vaccination as a test case to face the current and upcoming pandemics (WEF, 2020). These issues rather reflect a deeply mechanistic, top-down dominated approach and are not at all compatible with the principles circumscribed for example by PNI. Together with the current Status Quo of both the Italian case (as well as most EU-member states) who established an oppressive strategy equalling autocratic principles, are tools that no longer serve society. In fact, as the pandemic progressed so did the authorities became detached from their own people by acting out with all the executive powers available. Therein resides an implicate danger of falling back into an authorian kind of governance thought to be a thing of the past. This pandemic should not be an incentive to turn our attention away from more pressing issues but leave COVID-19 as it is - part of the annual influenza cycle. Therefore, we demand that authorities across Europe engage in a collaborative effort by i) refraining from protectionist ad-hoc actions like border-closures, ii) stop harassing the public with bureaucratic hurdles incurring exceptional hardship; iii) fully re-establish civil rights, iv) enforcing an open and publicly conducted debate about this crisis based on facts, 
and foremost v) question our mechanistic approach in how we deal with a bioaerosol that is combated with a bunker-mentality as if is a matter of life and death.

Eventually, it must boil down to a very fundamental issue: do we want to live in harmony with our socio-ecological environment and be part of it or do we want shut ourselves off and consider our life-support system a fierce full enemy? It is obvious that in the latter case sooner rather than later we are going to make ourselves redundant and eventually risk extinction bringing the Anthropocene to an abrupt end. To say it with the words of John Maynard Keynes: "The difficulty lies not so much in developing new ideas as in escaping from old ones".

\section{CONCLUSIONS}

Given the evidence provided, we think it is justified to assign anthropogenic causes to be at the origin of higher COVID-19 incidents. The specificity of the rate by which the number of infections spread and thus affected certain areas of northern Italy, shows strong correlations with persisting ground-level air pollution especially during the colder months of the year. Particularly $\mathrm{PM}_{10} / \mathrm{PM}_{2.5}$, $\mathrm{NO}_{2}$ and shortfalls within the Italian health-care system have aggravated the health crisis that followed thereafter. The physico-chemical cocktail in chronically polluted air is known to adversely affect resilience among the residence of the Po-Valley via suppressed immunological capabilities thereby i) being more susceptible to respiratory infections and at the same time ii) acts as a booster to the otherwise slow rate of increase in COVID-19 progression (Perone, 2021). Nonetheless did a press release from March 2020 by the Board of Directors (along with its signatory members) of the Italian Aerosol Society unanimously claim that a direct relationship between excessive groundlevel PM-concentration and the spread of SARS-CoV-2 infection incidents is pure speculation (IAS, 2020).

The events observed in hot-spots of northern Italy make it evident how deteriorating environmental conditions shift the eco-dynamic balance towards the emergence of man-made diseases (Madl and Hussain, 2011). This observation is an ongoing debate in many fields, even with regards to chronic exposure to electromagnetic fields-although denied by the ICNIRP online statement (ICNIRP, 2020), the COVID-19-EMF-link cannot be excluded as persistent exposure to EMFs is known to induce distressing effects and ultimately resilience in biological systems (Milham, 2017; Nasim and Kim, 2017). Since epigenetic flexibility regards plasticity during embryonic development, that stretches beyond the post-natal phase into adulthood, there is an undeniable link between epigenetic imprinting due to long-term exposure (to unhealthy air, water and food) and developmental disorders, as well as the onset of a disease dynamics that can manifest itself either at a very early age or as witness during recent events among the elderly (Madl, 2012). The elevated fatalities observed during the first wave (months of March-April 2020), particularly within the age group ( $\geq 80$ yrs) bring us to the conclusion that prudent avoidance, prevention as well as ALARA (As Low As Reasonably Achievable) principles should be applied with regards to the sustainability of anthropogenic settlements. In order to work out the best possible strategies in how to tackle the current crisis the advising governmental panel of experts needs to be enlarged by including all scientific disciplines, and not be restricted to selected medical experts only. We also want to recall that the application of the precautionary principle in health strategies and policies, taking in account the specificity and the anamnesis of individuals, mostly for mass health campaigns should be on the order of the day; i.e., i) consider a vaccination moratorium for the age group $>65$ years; ii) implement the full range of medical therapies available (allopathic and complementary) to boost resilience, iii) raise awareness on the importance of a healthy lifestyle and a healthy environment, iv) reduce the psychological stress burden by providing unbiased news about the real virulence of the virus and v) tackle the persisting environmental emergency especially in most affected areas such as the Po-Valley.

\section{REFERENCES}

Addey, D., Shephard, A. (2012). Incidence, causes, severity and treatment of throat discomfort: A four-region online questionnaire survey. BMC Ear Nose Throat Disord. 12, 9. https://doi.org/ 10.1186/1472-6815-12-9 
Agenzia Regionale per la Protezione dell'Ambiente (ARPA) (2020). Agenzia regionale per la protezione dell'ambiente della Lombardia. https://www.arpalombardia.it/Pages/Aria/qualitaaria.aspx (accessed 20 May 2020).

Ahlawat, A., Wiedensohler, A., Mishra, S.K. (2020). an overview on the role of relative humidity in airborne transmission of SARS-CoV-2 in indoor environments. Aerosol Air Qual. Res. 20, 1856-1861. https://doi.org/10.4209/aaqr.2020.06.0302

AirVisual (2020). Real time 3D-animated air pollution map. Incen AG, Staad (CH). https://www.iqair.com/earth?nav (accessed 20 May 2020).

Andree, B.P.J. (2020). Incidence of Covid-19 and Connections with Air Pollution Exposure: Evidence from the Netherlands. World Bank Policy Research Working Paper No. 9221. https://ssrn.com/abstract=3584842 (accessed 20 May 2020).

Arvay, C. (2020). Genetische Impfstoffe gegen COVID-19: Hoffnung oder Risiko? Schweiz Aerztezeitung 101, 862-864. https://doi.org/10.4414/saez.2020.18982 (German only)

Aubrit, F., Perugi, F., Léon, A., Guéhenneux, F., Champion-Arnaud, P., Lahmar, M., Schwamborn, K. (2015). Cell substrates for the production of viral vaccines. Vaccine 33, 5905-5912. https://doi.org/10.1016/j.vaccine.2015.06.110

Babu, S.R., Rao, N.N., Kumar, S.V., Paul, S., Pani, S.K. (2020). Plausible role of environmental factors on COVID-19 transmission in the megacity Delhi, India. Aerosol Air Qual. Res. 20, 20752084. https://doi.org/10.4209/aaqr.2020.06.0314

Baum, C., Kustikova, O., Modlich, U., Li, Z.X., Fehse, B. (2006). Mutagenesis and oncogenesis by chromosomal insertion of gene transfer vectors. Hum. Gene Ther. 17, 253-263. https://doi.org/ 10.1089/hum.2006.17.253

Benbrahim-Tallaa, L., Baan, R.A., Grosse, Y., Lauby-Secretan, B., Ghissassi, F.E., Bouvard, V., Guha, N., Loomis, D., Straif, K. (2012). Carcinogenicity of diesel-engine and gasoline-engine exhausts and some nitroarenes. Lancet Oncol. 13, 663-664. https://doi.org/10.1016/S1470-2045(12)7 0280-2

Bergamo News (2019a). Vaccino antiinfluenzale: A Bergamo ordinate 185.000 dosi. https://www bergamonews.it/2019/10/21/vaccinazione-antinfluenzale-a-bergamo-ordinate-185-000-dosi-divaccino/332164/?fbclid=IwAR1glyhj6RQOqOp8YbBf5oLMrknl8P4DyQ-k_GsVicLA-vWuTFwilT SUnzM (accessed May, 2020).

Bergamo News (2019b). Emergenza Meningite, Vaccinate 34mila persone tra Brescia e Bergamo. https://www.bsnews.it/2020/01/18/meningite-vaccinate-34mila-persone-tra-brescia-ebergamo/?fbclid=IwAR1bsaQy4Ppd21k4WLPkYYMnpiBY5tEtdk5gEH25rZfrGjTDyl_RnxNytNU (accessed May, 2020).

Bhattacharjee, S. (2020). Statistical investigation of relationship between spread of coronavirus disease (COVID-19) and environmental factors based on study of four mostly affected places of China and five mostly affected places of Italy. arXiv:2003.11277. https://arxiv.org/abs/2003. 11277

Bourdrel, T., Bind, M.A., Béjot, Y., Morel, O., Argacha, J.F. (2017). Cardiovascular effects of air pollution. Arch. Cardiovasc. Dis. 110,634-642. https://doi.org/10.1016/j.acvd.2017.05.003

Brain Research Fondazione (BRF) (2020). Osservatorio Suicidi COVID-19 (Suicide Observatory COVID-19, Italian only). Brain Research Foundation, Lucca (ITA). https://www.fondazionebrf.o rg/osservatorio-suicidi-covid-19/ (accessed February, 2021).

Buda, S., Preuss, U., Wedde, M., Duerrwald, R. (2019). Effectiveness of vaccination against seasonal influenza - vaccine effectiveness (Wirksamkeit der Impfung gegen saisonale Influenza - Impfeffektivität). in: Report on the Epidemiology of Influenza in Germany, Season 2018/19 (Bericht zur Epidemiologie der Influenza in Deutschland, Saison 2018/19), Robert KochInstitute, Berlin (FRG). https://doi.org/10.25646/6232

Cabanillas, B., Akdis, C., Novak, N. (2020). Allergic reactions to the first COVID-19 vaccine: A potential role of Polyethylene glycol? Allergy 76, 1617-1618. https://doi.org/10.1111/all.14711

Cao, C., Jiang, W.J., Wang, B.Y., Fang, J.H., Lang, J.D., Tian, G., Jiang, J.K., Zhu, T.F. (2014) Inhalable microorganisms in Beijing's $\mathrm{PM}_{2.5}$ and $\mathrm{PM}_{10}$ pollutants during a severe smog event. Environ. Sci. Technol. 48, 1499-1507. https://doi.org/10.1021/es4048472

Cartenì, A., Francesco L.D., Martino, M. (2020). How mobility habits influenced the spread of the COVID-19 pandemic: Results from the Italian case study Sci. Total Environ. 741, 140489. https://doi.org/10.1016/j.scitotenv.2020.140489 
Centers for Disease and Control Prevention (CDC) (2020a). Respirator Trusted-Source Information - Surgical N95 Respirators. The National Personal Protective Technology Laboratory (NPPTL), National Institute for Occupational Safety and Health of the Centers for Disease and Control Prevention. https://www.cdc.gov/niosh/npptl/topics/respirators/disp_part/respsource3surg icaln95.html (accessed in May 2020).

Centers for Disease and Control Prevention (CDC) (2020b). Weekly Updates by Select Demographic and Geographic Characteristics - Provisional Death Counts for Coronavirus Disease 2019 (COVID-19). Center for Disease Control. https://www.cdc.gov/nchs/nvss/vsrr/covid_weekly/i ndex.htm (accessed in June 2020).

Centers for Disease and Control Prevention (CDC) (2021). Emerging SARS-CoV-2 Variants" Centers for Disease Control and Prevention. Retrieved 4 January 2021. https://www.cdc.gov/coronavi rus/2019-ncov/more/science-and-research/scientific-brief-emerging-variants.html (accessed in February 2021).

Cesaroni, G., Badaloni, C., Gariazzo, C., Stafoggia, M., Sozzi, R., Davoli, M., Forastiere, F. (2013). Long-term exposure to urban air pollution and mortality in a cohort of more than a million adults in Rome. Environ. Health Perspect. 121, 324-331. https://doi.org/10.1289/ehp.1205862

Cesaroni, G., Forastiere, F., Stafoggia, M., Andersen, Z.J., Badaloni, C., Beelen, R., Caracciolo, B., Faire, U. de, Erbel, R., Eriksen, K.T., Fratiglioni, L., Galassi, C., Hampel, R., Heier, M., Hennig, F., Hilding, A., Hoffmann, B., Houthuijs, D., Jöckel, K.-H., Korek, M., et al. (2014). Long term exposure to ambient air pollution and incidence of acute coronary events: Prospective cohort study and meta-analysis in 11 European cohorts from the ESCAPE Project. BMJ 348, f7412. https://doi.org/10.1136/bmj.f7412

Chauhan, A.J., Johnston, S.L. (2003). Air pollution and infection in respiratory illness. Br. Med. Bull. 68, 95-112. https://doi.org/10.1093/bmb/ldg022

Chen, G., Zhang, W.Y., Lia, S.S., Williams, G., Liu, C., Morgan, G.G., Jaakkola, J.J.K., Guo, Y.M. (2017). Is short-term exposure to ambient fine particles associated with measles incidence in China? A multi-city study. Environ. Res. 156, 306-311. https://doi.org/10.1016/j.envres.2017. 03.046

Chen, P.S., Tsai, F.T., Lin, C.K., Yang, C.Y., Chan, C.C., Young, C.Y., Lee, C.H. (2010). Ambient influenza and avian influenza virus during dust storm days and background days. Environ. Health Perspect. 118, 1211-1216; https://doi.org/10.1289/ehp.0901782

Chimot, J. (2021). TROPOspheric Monitoring Instrument (TROPOMI) - A journey in Earth observation satellite science. https://julien-chimot-research.blog/tropospheric-monitoringinstrument-tropomi/ (accessed in May 2021).

Ciencewicki, J., Jaspers, I. (2007). Air pollution and respiratory viral infection. Inhalation Toxicol. 19, 1135-1146. https://doi.org/10.1080/08958370701665434

Cohen, A.J., Brauer, M., Burnett, R., Anderson, H.R., Frostad, J., Estep, K., Balakrishnan, K., Brunekreef, B., Dandona, L., Dandona, R., Feigin, V., Freedman, G., Hubbell, B., Jobling, A., Kan, H., Knibbs, L., Liu, Y., Martin, R., Morawska, L., Pope, C.A., et al. (2017). Estimates and 25-year trends of the global burden of disease attributable to ambient air pollution: An analysis of data from the Global Burden of Diseases Study 2015. Lancet 389, 1907-1918. https://doi.org/10.10 16/S0140-6736(17)30505-6

Cole, M.A., Ozgen, C., Strobl, E. (2020). Air pollution exposure and COVID-19. IZA Discussion Paper No. 13367; ISSN: 2365-9793. https://ssrn.com/abstract=3628242 (accessed June 2020).

Comuni Italiani (2020). Province of Bergamo and city of Bergamo. Census Data from 2016. http://www.comuni-italiani.it/016/index.html (accessed May 2020).

Coors, E.A., Seybold, H., Merk, H.F., Mahler, V. (2005). Polysorbate 80 in medical products and nonimmunologic anaphylactoid reactions. Ann. Allergy Asthma Immunol. 95, 593-599. https://doi.org/10.1016/S1081-1206(10)61024-1

Couch, R.B. (1981). Viruses and indoor air pollution. Bull. N. Y. Acad. Med. 57, 907-921.

Cowling, B.J., Fang, V.J., Nishiur, H., Chan, K.H., Ng, S., Ip, D.K.M., Chiu, S.S., Leung, G.M., Peiris, J.S.M. (2012). Increased risk of noninfluenza respiratory virus infections associated with receipt of inactivated influenza vaccine. Clin. Infect. Dis. 54, 1778-1783. https://doi.org/10.1093/cid/c is 307

Despres, V.R., Huffman, J.A., Burrows, S.M., Hoose, C., Safatov, A.S., Buryak, G., FroehlichNowoisky, J., Elbert, W., Andreae, M.O., Poeschl, U., Jaenicke, R. (2012). Primary biological 
aerosol particles in the atmosphere: A review. Tellus B 64, 15598. https://doi.org/10.3402/te llusb.v64i0.15598

deVrieze, J. (2021). Pfizer's vaccine raises allergy concerns. Science 371, 10-11. https://doi.org/1 $0.1126 /$ science.371.6524.10

Dockery, D.W., Pope, C.A., Xu, X.P., Spengler, J.D., Ware, J.H., Fay, M.E., Ferris, B.G., Speizer, F.E. (1993). An association between air pollution and mortality in six U.S. Cities. N. Engl. J. Med. 329, 1753-1759. https://doi.org/10.1056/NEJM199312093292401

Doremalert, N., Bushmaker, T., Morris, D.H., Holdbrook, M.G., Gamble, A., Williamson, B.N., Tamin, A., Harcourt, J.L., Thornbug, N.J., Gerber, S.I., Lloyd-Smith, J.O., Witt, E., Munster, V.J. (2020). Aerosol and surface stability of SARS-CoV-2 as compared with SARS-CoV-1. N. Engl. J. Med. 382, 1564-1567. https://doi.org/10.1056/NEJMc2004973

Doshi, P. (2020a). Covid-19 vaccine trial protocols released. BMJ 371, m4058. https://doi.org/10.1136/bmj.m4058

Doshi, P. (2020b). Will covid-19 vaccines save lives? Current trials aren't designed to tell us. BMJ 371, m4037. https://doi.org/10.1136/bmj.m4037

Duguid, J.P. (1946). The size and the duration of air-carriage of respiratory droplets and dropletnuclei. J. Hyg. 44, 471-479.

EBMPHET Consortium (2020). COVID-19 severity in Europe and the USA: Could the seasonal influenza vaccination play a role? Social Science Research Network, Rochester, NY. https://doi.org/10.2139/ssrn.3621446

Engelbrecht, T., Köhnlein, C. (2007). Virus Mania - Avian Flu (H5N1), Cervical Cancer (HPV), SARS, BSE, Hepatitis C, AIDS, Polio. How the Medical Industry Continually Invents Epidemics Making Billion-Dollar Profits at our Expense. Trafford Publishing, Victoria (BC).

EuroMomo (2020). European monitoring of excess mortality for public health action. http://www.euromomo.eu (accessed 20 May 2020).

European Centre for Disease Prevention and Control (ECDC) (2018). Seasonal influenza vaccination and antiviral use in EU/EEA Member States - Overview of vaccine recommendations for 2017 2018 and vaccination coverage for 2015-2016 and 2016-2017 influenza season. European Centre for Disease Prevention and Control. https://www.ecdc.europa.eu/sites/default/files/d ocuments/seasonal-influenza-antiviral-use-2018.pdf (accessed May 2020).

European Centre for Disease Prevention and Control ECDC (2021). Risk related to the spread of new SARS-CoV-2 variants of concern in the EU/EEA - first update. European Centre for Disease Prevention and Control. https://www.ecdc.europa.eu/sites/default/files/documents/COVID19-risk-related-to-spread-of-new-SARS-CoV-2-variants-EU-EEA-first-update.pdf (accessed in February 2021).

European Space Agency (ESA) (2020). Coronavirus lockdown leading to drop in pollution across Europe. European Space Agency. https://www.esa.int/Applications/Observing_the_Earth/Co pernicus/Sentinel-5P/Coronavirus_lockdown_leading_to_drop_in_pollution_across_Europe (accessed May 2020).

European Union (EU) (1999). Council Directive 1999/30/EC of 22 April 1999 relating to limit values for sulphur dioxide, nitrogen dioxide and oxides of nitrogen, particulate matter and lead in ambient air. Official Journal of the European Union, L163(29/06/1999):41-60. http://eurlex.europa.eu/LexUriServ/LexUriServ.do?uri=OJ:L:1999:163:0041:0060:EN:PDF (accessed 20 May 2020).

European Union (EU) (2008). Council Directive 2008/50/EC of 21 May 2008 on ambient air quality and cleaner air for Europe. Official Journal of the European Union, L152(11/06/2008):1-44. https://eur-lex.europa.eu/legal-content/EN/TXT/?uri=CELEX:32008L0050 (accessed 20 May 2020).

European Union (EU) (2016). Charter of Fundamental Rights of the European Union. Official Journal C202:389-405. https://eur-lex.europa.eu/legal-content/EN/TXT/PDF/?uri=CELEX:12016P/TXT (accessed February 2021).

EuroStat (2020a). Life expectancy at birth by sex. European Commission. https://ec.europa.eu/ eurostat/databrowser/view/tps00205/default/bar?lang=en (accessed May 2020).

EuroStat (2020b). Mortality and life expectancy statistics. European Commission. https://ec.europa. eu/eurostat/statistics-explained/index.php/Mortality_and_life_expectancy_statistics (accessed May 2020). 
EuroStat (2020c). Vaccination against influenza of population aged 65 and over. European Commission. https://ec.europa.eu/eurostat/web/products-datasets/-/hlth_ps_immu (accessed May 2020).

Fattorini, D., Regolim, F. (2020). Role of the atmospheric pollution in the COVID-19 outbreak risk in Italy. Environ. Poliut. 264, 114732. https://doi.org/10.1016/j.envpol.2020.114732

Feng, Y., Marchal, T., Sperry, T., Yi, H. (2020). Influence of wind and relative humidity on the social distancing effectiveness to prevent COVID-19 airborne transmission: A numerical study. J. Aerosol Sci. 147, 105585. https://doi.org/10.1016/j.jaerosci.2020.105585

Gan, W.Q., Koehoorn, M., Davies, H.W., Demers, P.A., Tamburic, L., Brauer, M. (2011). Long-term exposure to traffic-related air pollution and the risk of coronary heart disease hospitalization and mortality. Environ. Health Perspect. 119, 501-507. https://doi.org/10.1289/ehp.1002511

Gapp, K., Bohacek, J., Grossmann, J., Brunner, A.M., Manuella, F., Nanni, P., Mansuy, I.M. (2016). Potential of environmental enrichment to prevent transgenerational effects of paternal trauma. Neuropsychopharmacology 41, 2749-2758. https://doi.org/10.1038/npp.2016.87

Gardner, L., Dong, E., CSSE (2020). The COVID-19 Testing Insight Initiative. Coronavirus Resource Center. Center for Systems Science and Engineering at John Hopkins University. https://coronavirus.jhu.edu/map.html (accessed 20 May 2020).

Gatti, A., Montanari, S. (2008). Nanopathology the health impact of nanoparticles. Pan Stanford Publishing, Singapore.

Gatti, A., Montanarim, S. (2015). Case studies in Nanotoxicology and Particle toxicology. Akademic Press Elsevier Publisher, London (UK).

Gaunt, E.R., Hardie, A., Claas, E.C., Simmonds, P., Templeton, K.E. (2010). Epidemiology and clinical presentations of the four human coronaviruses 229E, HKU1, NL63, and OC43 detected over 3 years using a novel multiplex real-time PCR method. J. Clin. Microbiol. 48, 2940-2947. https://doi.org/10.1128/JCM.00636-10

Ghorani-Azam, A., Riahi-Zanjani, B., Balali-Mood, M. (2016). Effects of air pollution on human health and practical measures for prevention in Iran. J. Res. Med. Sci. 21, 65. https://doi.org/ 10.4103/1735-1995.189646

Gomes, M.G.M., Corder, R.M., King, J.G., Langwig, K.E., Souto-Maior, C., Carneiro, J., Goncalves, G. Penha-Goncalves, C., Ferreira, M.U., Aguas, R. (2020). Individual variation in susceptibility or exposure to SARS-CoV-2 lowers the herd immunity threshold. medRxiv 2020.04.27.20081893. https://doi.org/10.1101/2020.04.27.20081893

Hadei, M., Hopke, P.K., Jonidi, A., Shahsavani, A. (2020). A letter about the airborne transmission of SARS-CoV-2 based on the current evidence. Aerosol Air Qual. Res. 20, 911-914. https://doi.org/10.4209/aaqr.2020.04.0158

Hardin, G. (1968). The Tragedy of the commons. Science 162, 1243-1248. https://doi.or $\mathrm{g} / 10.1126 /$ science.162.3859.1243

Harm, W. (1980). Biological effect of UV radiation. Cambridge University Press (UK).

Hasson, S., Al-Busaidi, J., Sallam, T. (2015). The past, current, and future trends in DNA vaccine immunisations. Asian Pac. J. Trop. Biomed. 5, 344-353. https://doi.org/10.1016/S2221-1691(1 5)30366-X

Heymann, D.L., Shindo, N. (2020). COVID-19: What is next for public health? Lancet 395, 542545. https://doi.org/10.1016/S0140-6736(20)30374-3

Hofmann, W. (2011). Modelling inhaled particle deposition in the human lung - A review. J. Aerosol Sci. 42, 693-724. https://doi.org/10.1016/j.jaerosci.2011.05.007

Hsee, C.K., Ruan, B. (2016). The pandora effect: The power and peril of curiosity. Psychol. Sci. 27, 659-666. https://doi.org/10.1177/0956797616631733

Hsiao, T.C., Chuang, H.C., Griffith, S.M., Chen, S.J., Young, L.H. (2020). COVID-19: An aerosol's point of view from expiration to transmission to viral-mechanism. Aerosol Air Qual. Res. 20, 905-910. https://doi.org/10.4209/aaqr.2020.04.0154

International Commission on Non-lonizing Radiation Protection (ICNIRP) (2020). COVID-19 and RF EMF. https://www.icnirp.org/en/activities/news/news-article/covid-19.html (accessed May 2020).

loannidis, J.P.A. (2020). Coronavirus disease 2019: The harms of exaggerated information and nonevidence-based measures. Eur. J. Clin. Invest. 50, e13222. https://doi.org/10.1111/eci.13222

Ioannidis, J.P.A., Axfors, C., Contopoulos-loannidis, D.G. (2020). Population-level COVID-19 mortality risk for non-elderly individuals overall and for non-elderly individuals without underlying 
diseases in pandemic epicenters. Environ. Res. 188, 109890. https://doi.org/10.1016/j.envres. 2020.109890

Istituto Superiore di Sanità (ISS) (2020a). Characteristics of COVID-19 patients dying in Italy. L'epidemiologia per la sanità pubblica, Istituto Superiore di Sanità. Roma (IT). https://www.epi centro.iss.it/coronavirus/sars-cov-2-decessi-italia (accessed May 2020).

Istituto Superiore di Sanità (ISS) (2020b). Characteristics of SARS-CoV-2 patients dying in Italy Report based on available data on May $21^{\text {st }}$, 2020. Istituto Superiore di Sanità. Roma (IT). https://www.epicentro.iss.it/en/coronavirus/bollettino/Report-COVID-2019_21_may_2020.pdf (accessed May 2020).

Italian Aerosol Society (IAS) (2020). Information on the relationship between air pollution and the spread of COVID-19. Italian Aerosol Society (Società Italiana di Aerosol), Bologna (IT). http://www.iasaerosol.it/attachments/article/96/Nota_Informativa_IAS_English.pdf (accessed in May 2020).

Jackson, L.A., Anderson, E.J., Rouphael, N.G., Roberts, P.C., Makhene, M., Coler, R.N., McCullough, M.P., Chappell, J.D., Denison, M.R., Stevens, L.J., Pruijssers, A.J., McDermott, A., Flach, B., Doria-Rose, N.A., Corbett, K.S., Morabito, K.M., O’Dell, S., Schmidt, S.D., II, P.A.S., Padilla, M., et al. (2020). An mRNA Vaccine against SARS-CoV-2 - Preliminary Report. N. Engl. J. Med. 383, 1920-1931. https://doi.org/10.1056/NEJMoa2022483

Jiang, S. (2020). Don't rush to deploy COVID-19 vaccines and drugs without sufficient safety guarantees. Nature 579, 321; https://doi.org/10.1038/d41586-020-00751-9

King, A.M.Q., Adams, M.J., Carstens, E.B., Lefkowitz, E.J. (2011). Virus Taxonomy $-9^{\text {th }}$ Report of the International Committee on Taxonomy of Viruses. Academic Press / Elsevier, Amsterdam.

Kissling, E., Rose, A., Emborg, H.-D., Gherasim, A., Pebody, R., Pozo, F., Trebbien, R., Mazagatos, C., Whitaker, H., Valenciano, M., Group, E.I. (2019). Interim 2018/19 influenza vaccine effectiveness: Six European studies, October 2018 to January 2019. Eurosurveillance 24, 1900121. https://doi.org/10.2807/1560-7917.ES.2019.24.1900121

Kochi, A.N., Tagliari, A.P., Forleo, G.B., Fassini, G.M., Tondo, C. (2020). Cardiac and arrhythmic complications in patients with COVID-19. J. Cardiovasc. Electrophysiol. 31, 1003-1008. https://doi.org/10.1111/jce.14479

Kucirka, L.M., Lauer, S.A., Laeyendecker, O., Boon, D., Lessler, J. (2020). Variation in false-negative rate of reverse transcriptase polymerase chain reaction-Based SARS-CoV-2 tests by time since exposure. Ann. Intern. Med. 173, 262-267. https://doi.org/10.7326/M20-1495

Lazzerini, P.E., Boutjdir, M., Capecchi, P.L. (2020). COVID-19, arrhythmic risk and inflammation: Mind the Gap! Circulation 142, 7-9. https://doi.org/10.1161/CIRCULATIONAHA.120.047293

Lednicky, J.A., Shankar, S.N., Elbadry, M.A., Gibson, J.C., Alam, M.M., Stephenson, C.J., EigurenFernandez, A., Morris, J.G., Mavian, C.N., Salemi, M., Clugston, J.R., Wu, C.Y. (2020). Collection of SARS-CoV-2 virus from the air of a clinic within a university student health care center and analyses of the viral genomic sequence. Aerosol Air Qual. Res. 20, 1167-1171. https://doi.org/ 10.4209/aaqr.2020.05.0202

LeQuéré, C., Peters, G.P., Friedlingstein, P., Andrew, R.M., Canadell, J.G., Davis, S.J., Jackson, R.B., Jones, M.W. (2021). Fossil $\mathrm{CO}_{2}$ emissions in the post-COVID-19 era. Nat. Clim. Chang. 11, 197199. https://doi.org/10.1038/s41558-021-01001-0

Li, Y.C., Bai, W.Z., Hashikawa, T. (2020a). The neuroinvasive potential of SARS-CoV2 may play a role in the respiratory failure of COVID-19 patients. J. Med. Virol. 92, 552-555. https://doi.org/ 10.1002/jmv.25728

Li, Y.G., Qian, H., Hang, J., Chen, X.G., Hong, L., Liang, P., Li, J.S., Xiao, S.L., Wei, J.J., Liu, L., Kang, M. (2020b). Evidence for probable aerosol transmission of SARS-CoV-2 in a poorly ventilated restaurant. medRxiv 2020.04.16.20067728. https://doi.org/10.1101/2020.04.16.20067728

Lim, E.C., Seet, R.C., Lee, K H., Wilder-Smith, E.P., Chuah, B.Y., Ong, B.K. (2006). Headaches and the N95 face-mask amongst healthcare providers. Acta Neurol. Scand. 113, 199-202. https://doi.org/10.1111/j.1600-0404.2005.00560.x

Liu, S., Wang, J., Liu, Y., Xu, Y., Che, X., Gu, W., Du, J., Zhang, X., Xu, E. (2017). Survey of contraindications in children's routine vaccination in Hangzhou, China. Hum. Vaccin. Immunother. 13, 1539-1543. https://doi.org/10.1080/21645515.2017.1304868

Lodovici, M., Bigagli, E. (2011). Oxidative stress and air pollution exposure. J. Toxicol. 2011, 487074. https://doi.org/10.1155/2011/487074 
Lolli, S., Chen, Y.C., Wang, S.H., Vivone, G. (2020). Impact of meteorological conditions and air pollution on COVID-19 pandemic transmission in Italy. Sci. Rep. 10, 16213. https://doi.org/10. 1038/s41598-020-73197-8

Loudon, R.G., Roberts, R.M. (1966). Droplet expulsion from the respiratory tract. Am. Rev. Respir. Dis. 95, 435-442.

Lurie, N., Saville, M., Hatchett, R., Halton, J. (2020). Developing COVID-19 vaccines at pandemic speed. N. Engl. J. Med. 382, 1969-1973. https://doi.org/10.1056/NEJMp2005630

Lyons-Weiler, J. (2020). Pathogenic priming likely contributes to serious and critical illness and mortality in COVID-19 via autoimmunity. J. Transl. Autoimmun. 3, 100051. https://doi.org/10. 1016/j.jtauto.2020.100051

MacIntyre, C.R., Seale, H., Dung, T.C., Hien, N.T., Nga, P.T., Cughtai, A.A., Rahman, B., Dwyer, D.E., Wang Q.Y. (2015). A cluster randomised trial of cloth masks compared with medical masks in healthcare workers. BMJ Open 5, e006577. https://doi.org/10.1136/bmjopen-2014-006577

Madl, P. (2012). Exposure to nano-sized particles and the emergence of contemporary diseases with a focus on epigenetics. in: Khare, M. (Ed.), Air Pollution - Monitoring, Modelling and Health. IntechOpen, Rijeka, Ch. 14. https://doi.org/10.5772/31935

Madl, P., DeFilippis, A., Tedeschi, A. (2020). Effects of ultra-weak fractal electromagnetic signals on the aqueous phase in living systems: A test-case analysis of molecular rejuvenation markers in fibroblasts. Electromagn. Biol. Med. 239, 1762634. https://doi.org/10.1080/15368378.2020. 1762634

Madl, P., Hussain, M. (2011). Lung deposition predictions of airborne particles and the emergence of contemporary diseases -Part II. theHealth 2, 101-107.

Mandavilli, A. (2020). 239 experts With One Big Claim: The Coronavirus Is Airborne. New York Times. https://www.nytimes.com/2020/07/04/health/239-experts-with-one-big-claim-thecoronavirus-is-airborne.html (accessed July 2020).

Mao, L., Jin, H.J., Wang, M.D., Hu, Y.; Chen, S.C., He, Q.W., Chang, J., Hong, C.D., Zhou, Y.F., Wang, D., Miao, X.P., Li, Y.N., Hu, B. (2020). Neurologic manifestations of hospitalized patients with coronavirus disease 2019 in Wuhan, China. JAMA Neurol. 77, 683-690. https://doi.org/10.100 1/jamaneurol.2020.1127

Marino, E., Caruso, M., Campagna, D., Polosa, R. (2015). Impact of air quality on lung health: Myth or reality? Ther. Adv. Chronic Dis. 6, 286-298. https://doi.org/10.1177/2040622315587256

Marongiu, F., Grandone, E., Barcellona, D. (2020). Pulmonary thrombosis in 2019-nCoV pneumonia? J. Thromb. Haemost. 18, 1511-1513. https://doi.org/10.1111/jth.14818

Martuzzi, M., Mitis, F., lavarone, I., Serinelli, M. (2006). Health impact of PM10 and ozone in 13 Italian cities. WHO Europe, Copenhagen (DK).

McIntosh, K. (1974). Coronaviruses: A comparative review. in: Arber, W., Haas, R., Henle, W., Hofschneider, P.H., Jerne, N.K., Koldovský, P., Koprowski, H., Maaløe, O., Rott, R., Schweiger, H.G., Sela, M., Syruček, L., Vogt, P.K., Wecker, E. (Eds.), Current Topics in Microbiology and Immunology, pp. 85-129. Springer, Berlin (FRG). https://doi.org/10.1007/978-3-642-65775-7_3

McRae, G.J., Russell, A.G. (1984). Dry deposition of nitrogen-containing species. in: Hicks B.B. (Ed.), Deposition both wet and dry Acid precipitation series, Boston, MA, p. 153.

Milham, S. (2010). Historical evidence that electrification caused the 20th century epidemic of "diseases of civilization". Med. Hypotheses 74, 337-345. https://doi.org/10.1016/j.mehy.200 9.08.032

Miller, M.R., Shaw, C.A., Langrish, J.P. (2012). From particles to patients: Oxidative stress and the cardiovascular effects of air pollution. Future Cardiol. 8, 577-602. https://doi.org/10.2217/fca. 12.43

Miller, M.R., McLean, S.G., Duffin, R., Lawal, A.O., Araujo, J.A., Shaw, C.A., Mills, N.L., Donaldson, K., Newby, D.E., Hadoke, P.W. (2013). Diesel exhaust particulate increases the size and complexity of lesions in atherosclerotic mice. Part. Fibre Toxicol. 10, 61. https://doi.org/10.118 6/1743-8977-10-61

Miller, M.R. (2020). Oxidative stress and the cardiovascular effects of air pollution. Free Radical Biol. Med. 151, 69-87. https://doi.org/10.1016/j.freeradbiomed.2020.01.004

Moelling, K. (2017). Viruses, More Friends Than Foes. World Scientific, Singapore. https://doi.org/10.1142/9789813147836_0001

Moelling, K., Broecker, F. (2020). Air Microbiome and Pollution: Composition and Potential 
Effects on Human Health, Including SARS Coronavirus Infection. J. Environ. Public Health 2020, 1646943. https://doi.org/10.1155/2020/1646943

Myint, S.H. (1995). Human Coronavirus Infections. in: Siddell, S.G. (Ed.), The Coronaviridae, Ch. 18. Springer (NY). https://doi.org/10.1007/978-1-4899-1531-3

Nasim, I., Kim, S.M. (2017). Human exposure to RF Fields in 5G downlink. arXiv:1711.03683v1. https://arxiv.org/pdf/1711.03683.pdf

Nickbakhsh, S., Mair, C., Matthews, L., Reeve, R., Johnson, P.C.D., Thorburn, F., Wissmann, B., Reynolds, A., McMenamin, J., Gunson, R.N., Murcia, P.R. (2019). Virus - virus interactions impact the population dynamics of influenza and the common cold. PNAS 116, 27142-27150. https://doi.org/10.1073/pnas.1911083116

Oberdoerster, G., Oberdoerster, E., Oberdoerster, J. (2005). Nanotoxicology: An emerging discipline evolving from studies of ultrafine particles. Environ. Health Perspect. 113, 823-839. https://doi.org/10.1289/ehp.7339

Oreskes, N., Conway, E.M. (2010). Merchants of Doubt: How a Handful of Scientists Obscured the Truth on Issues from Tobacco Smoke to Global Warming. Bloomsbury Press, London, UK.

Pan, M., Eiguren-Fernandez, A., Hsieh, H., Afshar-Mohajer, N., Hering, S.V., Lednicky, J., Fan, Z.H., Wu, C.Y. (2016). Efficient collection of viable virus aerosol through laminar-flow, water-based condensational particle growth. J. Appl. Microbiol. 120, 805-815. https://doi.org/10.1111/jam. 13051

Peng, L., Zhao, X.G., Tao, Y., Mi, S.Q., Huang, J., Zhang, Q.K. (2020). The effects of air pollution and meteorological factors on measles cases in Lanzhou, China. Environ. Sci. Pollut. Res. 27, 13524-13533. https://doi.org/10.1007/s11356-020-07903-4

Pepe, E., Bajardi, P., Gauvin, L. Privitera, F., Lake. B., Cattuto, C., Tizzon, M. (2020). COVID-19 outbreak response, a dataset to assess mobility changes in Italy following national lockdown. Sci. Data 7, 230. https://doi.org/10.1038/s41597-020-00575-2

Perone, G. (2020). The determinants of COVID-19 case fatality rate (CFR) in the Italian regions and provinces: An analysis of environmental, demographic, and healthcare factors. Sci. Total Environ. 755, 142523. https://doi.org/10.1016/j.scitotenv.2020.142523

Pirkis, J.A., Gunnell, D., Appleby, L., Morrissey, J. (2020). Trends in suicide during the covid-19 pandemic. BMJ 371, m4352. https://doi.org/10.1136/bmj.m4352

Prussin, A.J., Garcia, E.B., Marr, L.C. (2015). Total concentrations of virus and bacteria in indoor and outdoor air. Environ. Sci. Technol. Lett. 2, 84-88. https://doi.org/10.1021/acs.estlett.5b00050

Qin, N., Liang, P., Wu, C.Y., Wang, C.Q., Xiong, X., Wang, T.T., Zolfo, M., Segata, N., Qin, H.L., Knight, R., Gilbert, J.A., Zhu, T.F. (2020). Longitudinal survey of microbiome associated with particulate matter in a megacity. Genome Biol. 21, 55. https://doi.org/10.1186/s13059-02001964-x

Reiss, K., Bhakdi, S. (2020). Corona False Alarm? Facts and Figures, $1^{\text {st }}$ ed. Chelsea Green Publishing.

Remuzzi, A., Remuzzi, G. (2020). COVID-19 and Italy: What next? Lancet 395, 1225-1228. https://doi.org/10.1016/s0140-6736(20)30627-9

Reuters (2021). EU to propose digital vaccination passport in March, von der Leyen says. https://www.reuters.com/article/health-coronavirus-eu-von-der-leyen-idUSL5N2KZ28M (accessed March 2021).

Rockloev, J., Sjoedin, H., Wilder-Smith, A. (2020). COVID-19 outbreak on the Diamond Princess cruise ship: Estimating the epidemic potential and effectiveness of public health countermeasures. J. Travel Med. 27, taaa030. https://doi.org/10.1093/jtm/taaa030

Ryan, F. (2009). Virolution. FPR Books, London (UK).

Sajadi, M.M., Habibzadeh, P., Vintzileos, A., Shokouhi, S., Miralles-Wilhelm, F., Amoroso, A. (2020). Temperature, humidity, and latitude analysis to estimate potential spread and seasonality of coronavirus disease 2019 (COVID-19). JAMA Netw Open 3, e2011834. https://doi.org/10.1001/ jamanetworkopen.2020.11834

Schubert, C. (2016). Selbstzerstörung bei Stress? Autoimmunerkrankungen aus Sicht der psychoneuroimmunologischen Forschung (Self-destruction due to stress? Autoimmune diseases from the point of view of psycho-neuro-immunological research, German only). Deutsche Heilpraktiker-Zeitschrift 11, 30-34. https://doi.org/10.1055/s-0036-1579564

Schwab, K., Malleret, T. (2020). Covid-19: The Great Reset. World Economic Forum, Geneva (CH). 
Sedlmaier, N., Hoppenheidt, K., Krist, H., Lehmann, H., Lang, H., Buettner, M. (2009). Generation of avian influenza virus (AIV) contaminated fecal fine particulate matter ( $\mathrm{PM}_{2.5}$ ): Genome and infectivity detection and calculation of immission. Vet. Microbiol. 139, 1560-164. https://doi.org/10.1016/j.vetmic.2009.05.005

Seow, J., Graham, C., Merrick, B., Acors, S., Pickering, S., Steel, K.J.A., Hemmings, O., O’Byrne, A., Kouphou, N., Galao, R.P., Betancor, G., Wilson, H.D., Signell, A.W., Winstone, H., Kerridge, C., Huettner, I., Jimenez-Guardeño, J.M., Lista, M.J., Temperton, N., Snell, L.B., et al. (2020). Longitudinal observation and decline of neutralizing antibody responses in the three months following SARS-CoV-2 infection in humans. Nat. Microbiol. 5, 1598-1607. https://doi.org/10.1 038/s41564-020-00813-8

Shi, S.B., Qin, M., Shen, B., Cai, Y.L., Liu, T., Yang, F., Gong, W., Liu, X., Liang, J.J., Zhao, Q.Y., Huang, H., Yang, B., Huang, C.X. (2020). Association of Cardiac Injury with Mortality in Hospitalized Patients With COVID-19 in Wuhan, China. JAMA Cardiol. 5, 802-810. https://doi.org/10.1001/ jamacardio.2020.0950

Silva, D.R., Viana, V.P., Müller, A.M., Livi, F.P., Dalcina, T.R. (2014). Respiratory viral infections and effects of meteorological parameters and air pollution in adults with respiratory symptoms admitted to the emergency room. Influenza Other Respir. Viruses 8, 42-52. https://doi.org/10. 1111/irv.12158

Singh, J.A., Upshur, R.E.G. (2020). The granting of emergency use designation to COVID-19 candidate vaccines: Implications for COVID-19 vaccine trials. Lancet Infect Dis. 8, E103-E109. https://doi.org/10.1016/S1473-3099(20)30923-3

Sole, R., Elena, S.F. (2019). Viruses as Complex Adaptive Systems (Primers in Complex Systems) Princeton University Press, Princeton (NJ).

Spinato, G., Fabbris, C., Polesel, J., Cazzador, D., Borsetto, D., Hopkins, C., Boscolo-Rizzo, P. (2020). Alterations in smell or taste in mildly symptomatic outpatients with SARS-CoV-2 Infection. JAMA 323, 2089-2090. https://doi.org/10.1001/jama.2020.6771

Srivastava, A. (2020). COVID-19 and air pollution and meteorology-an intricate relationship: A review Chemosphere, 263, 1282-1297. https://doi.org/10.1016/j.chemosphere.2020.128297

Stemmler, K., Ammann, M., Donders, C., Kleffmann, J., George, C. (2006). Photosensitized reduction of nitrogen dioxide on humic acidas a source of nitrous acid. Nature, 440, 195-198. https://doi.org/10.1038/nature04603

Suhaimi, N.F., Jalaludin, J., Latif, M.T. (2020). Demystifying a possible relationship between COVID-19, air quality and meteorological factors: Evidence from Kuala Lumpur, Malaysia. Aerosol Air Qual. Res. 20, 1520-1529. https://doi.org/10.4209/aaqr.2020.05.0218

Sutcliffe, H. (2020). COVID-19: The 4 building blocks of the Great Reset. World Economic Forum. https://www.weforum.org/agenda/2020/08/building-blocks-of-the-great-reset (accessed February 2021).

Swartz, J.R., Hariri, A.R., Williamson, D.E. (2017). An epigenetic mechanism links socioeconomic status to changes in depression-related brain function in high-risk adolescents. Mol. Psychiatry 22, 209-214. https://doi.org/10.1038/mp.2016.82

Tang, N., Li, D., Wang, X., Sun, Z. (2020). Abnormal coagulation parameters are associated with poor prognosis in patients with novel coronavirus pneumonia. J. Thromb. Haemost. 18, 844847. https://doi.org/10.1111/jth.14768

Tyrrell, D.A., Almeida, J.D., Cunningham, C.H., Dowdle, W.R., Hofstad, M.S., Mclntosh, K., Tajima, M., Zakstelskaya, L.Y., Easterday, B.C., Kapikian, A., Bingham, R.W. (1975). Coronaviridae. Intervirology 5, 76-82. https://doi.org/10.1159/000149883

United Nations (UN) (2015). The Paris Agreement. United Nations Climate Change. https://unfccc. int/process-and-meetings/the-paris-agreement/the-paris-agreement (accessed February 2021).

Ura, T., Okuda, K., Shimada, M. (2014). Development in viral vector based vaccines. Vaccines 2, 624-641. https://doi.org/10.3390/vaccines2030624

Vaccine Adverse Event Reporting System (VAERS) (2021). Searching the VEARS database. Vaccine Adverse Event Reporting System. https://medalerts.org/vaersdb/index.php (accessed February 2021).

Vallero, D. (2014). Fundamentals of Air pollution, $5^{\text {th }}$ ed. Elsevier, Amsterdam (NL).

Villarreal, L.P. (2005). Viruses and the Evolution of Life. American Society for Microbiology Press, Washington (DC). 
Villarreal, L.P., Witzany, G. (2013). Rethinking quasispecies theory: From fittest type to cooperative consortia. World J. Biol. Chem. 4, 79-90. https://doi.org/10.4331/wjbc.v4.i4.79

Villarreal, L.P. (2015). Virolution Can Help Us Understand the Origin of Life. in: Kolb, V. (Ed.), Astrobiology - An Evolutionary Approach. CRC Press, Boca Raton (FL).

Walach, H., Hockertz, S. (2020). What association do political interventions, environmental and health variables have with the number of Covid-19 cases and deaths? A linear modeling approach. medRxiv 2020.06.18.20135012. https://doi.org/10.1101/2020.06.18.20135012

Watson, J., Whiting, P.F., Brush, J.E. (2020). Interpreting a covid-19 test result. BMJ 369, m1808. https://doi.org/10.1136/bmj.m1808

Wichmann, D., Sperhake, J.-P., Lütgehetmann, M., Steurer, S., Edler, C., Heinemann, A., Heinrich, F., Mushumba, H., Kniep, I., Schröder, A.S., Burdelski, C., de Heer, G., Nierhaus, A., Frings, D., Pfefferle, S., Becker, H., Bredereke-Wiedling, H., de Weerth, A., Paschen, H.R., SheikhzadehEggers, S., et al. (2020). Autopsy findings and venous thromboembolism in patients with COVID-19. Ann. Intern. Med. 173, 268-277. https://doi.org/10.7326/M20-2003

Wolff, G. (2020). Influenza vaccination and respiratory virus interference among Department of Defense personnel during the 2017-2018 influenza season. Vaccine 38, 350-354. https://doi.org/10.1016/j.vaccine.2019.10.005

Wood, D., Pereyra, M., Halfon, N., Hamlin, J., Grabowsky, M. (1995). Vaccination levels in Los Angeles public health centers: The contribution of missed opportunities to vaccinate and other factors. Am. J. Public Health 85, 850-853. https://doi.org/10.2105/ajph.85.6.850

World Economic Forum (WEF) (2020). Building Future Resilience to Global Risks. World Economic Forum, Davos (CH). https://www.weforum.org/agenda/2020/11/the-great-reset-building-futureresilience-to-global-risks/ (accessed February 2021).

World Health Organization (WHO) (2012). IARC: Diesel engine exhaust carcerogenic. International Agency for Research on Cancer (IARC), Press release No. 213. https://www.iarc.fr/newsevents/iarc-diesel-engine-exhaust-carcinogenic/ (accessed 20 May 2020).

World Health Organization (WHO) (2020a). Advice on the use of masks in the context of COVID19. WHO/2019-nCov/IPC_Masks/2020.4. https://www.who.int/publications/i/item/adviceon-the-use-of-masks-in-the-community-during-home-care-and-in-healthcare-settings-in-thecontext-of-the-novel-coronavirus-(2019-ncov)-outbreak (accessed 5 June 2020).

World Health Organization (WHO) (2020b). An unprecedented challenge: Italy's first response to COVID-19. https://www.saluteinternazionale.info/wp-content/uploads/2020/12/WHO_Repo rt_Zambon.pdf (accessed 13 May 2020).

World Health Organization (WHO) (2020c). Director-General's opening remarks at the media briefing on COVID-19 - 3 March 2020. https://www.who.int/dg/speeches/detail/who-directorgeneral-s-opening-remarks-at-the-media-briefing-on-COVID-19---3-march-2020 (accessed 20 May 2020.

World Health Organization (WHO) (2021). COVID-19 Vaccine AstraZeneca solution for injection. https://extranet.who.int/pqweb/sites/default/files/documents/WHO_PL_azd1222.pdf (accessed February 2021).

Xie, X.J., Li, Y.G., Sun, H.Q., Liu, L. (2009). Exhaled droplets due to talking and coughing. J. R. Soc. Interface 6, S703-S714. https://doi.org/10.1098/rsif.2009.0388.focus

Xu, R., Rahmandad, H., Gupta, M., DiGennaro, C., Ghaffarzadegan, N., Amini, N., Jalali, M.S. (2020). The modest impact of weather and air pollution on COVID-19 transmission. medRxiv 2020.05.05.20092627. https://doi.org/10.1101/2020.05.05.20092627

Yan, J., Grantham, M., Pantelic, J., deMesquita, B.J.P., Albert, B., Liu, F., Ehrman, S., Milton, D.K., Consortium, E. (2018). Infectious virus in exhaled breath of symptomatic seasonal influenza cases from a college community. PNAS 115, 1081-1086. https://doi.org/10.1073/pnas.17165 61115

Ye, Q., Fu, J.F., Mao, J.H., Shang, S.Q. (2016). Haze is a risk factor contributing to the rapid spread of respiratory syncytial virus in children. Environ. Sci. Pollut. Res. 23, 20178-20185. https://doi.org/10.1007/s11356-016-7228-6

Zhang, L., Vet, R., O’Brien, J.M., Mihele, C., Liang, Z., Wiebe, A. (2009). Dry deposition of individual nitrogen species at eight Canadian rural sites. J. Geophys. Res. 114, D02301. https://doi.org/1 $0.1029 / 2008 J$ D010640

Zhang, L.Z., Jackson, C.B., Mou, H.H., Ojha, A., Rangarajan, E.S., Izard, T., Farzan, M., Choe, H.Y. 
(2020). The D614G mutation in the SARS-CoV-2 spike protein reduces S1 shedding and increases infectivity. Scripps Research preprint. https://www.scripps.edu/news-and-events/pressroom/2020/20200611-choe-farzan-sars-cov-2-spike-protein.html (accessed June 2020).

Zoran, M.A., Savastru, R.S., Savastru, D.M., Tautan, M.N. (2020). Assessing the relationship between surface levels of $\mathrm{PM}_{2.5}$ and $\mathrm{PM}_{10}$ particulate matter impact on COVID-19 in Milan, Italy. Sci. Total Environ. 738, 139825. https://doi.org/10.1016/j.scitotenv.2020.139825 